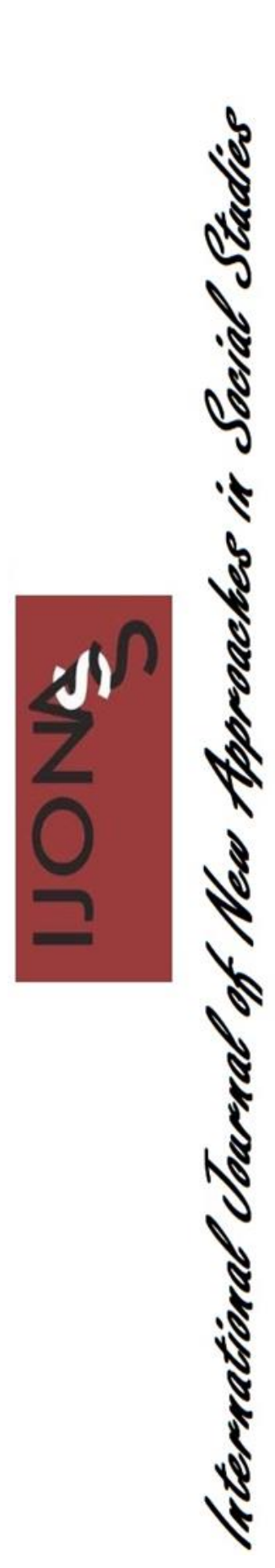

\title{
Tarih Konularının Öğretiminde Senkronik Yaklaşım Modeli ve Ölçekli Senkronik Tarih Şeritleri***
}

\author{
Ömür KIZIL ${ }^{1 *} @ \&$ Cengiz DÖNMEZ²@
}

Gönderilme Tarihi: 22 Kasım 2020

Kabul Tarihi: 10 Aralık 2020

DOI: $10.38015 /$ sbyy. 829592

\begin{abstract}
$\ddot{O} z:$
Tarihi olay ve olgular, zaman ve mekân içerisindeki başka olay ve olgularla bağlantılı şekilde ortaya çılkar. Diyakronik tarih anlaylşı, olay ve olgular arasindaki bu bağlantıyl, zaman içerisindeki bir nedensellik zincirine indirgemiştir. Bu durum, doğası gereği epistemolojik bir yapı olan tarih algısını mekân faktörünü göz ardı etmek suretiyle manipüle etmektedir. Tarih yazımında, karşılaş̧tırmalı tarih yönteminin kullanılmaya başlaması, bu sorunu büyük ölçüde ortadan kaldırmıştır. Ancak karşılaştırmalı tarih yönteminin, tarih konularının öğretimi üzerinde henüz sistematik bir etkisi görülmemiştir. Bu çalışmada karş̧laştırmalı tarih ve senkronik tarih şeridi çalışmalarından hareketle; tarih konularının öğretiminde kullanılabilecek bir senkronik yaklaşım modeli ortaya konulmuştur. Bu bağlamda, model kapsamında kullanılabilecek senkronik tarih şeritleri de hazırlanmuştır. Avrupa'da ve Amerika Birleşik Devletleri'nde çok eski örneklerine rastlansa da ülkemizde bu alanda çok az sayıda çalışma vardır. Var olan çalı̧̧malar da senkronik tarih şeritleri ile ilgili literatüre herhangi bir yenilik katamamışlardır. Avrupa 'da ve ABD'de hazırlanan senkronik tarih şeritlerinde, mekân faktörünün Avrupa ve ABD lehine manipüle edildiği görülmektedir. Bu durum Batı Uygarllğının, diğer uygarlıklara nazaran daha "büyük" ve daha "önemli" görünecek şekilde temsil edilmesine sebep olmaktadır. Dolaylslyla senkronik tarih şeritlerinde mekân faktörü için standart bir yöntemin bulunmaması objektif çalışmaların üretimi konusunda sorun yaratmaktadır. Bu çalışmada, senkronik tarih şeritleri ile ilgili bu sorunu çözen ve objektif zaman-mekânsal temsili mümkün kilan bir yöntem geliştirilmişs ve uygulanmiş̧ır. Hazırlanan senkronik tarih şeridi, 1789-2018 yilları arasında Avrupa, Türkistan, Ortadoğu ve Kuzey Afrika'daki tarihi süreci zamanmekânsal olarak haritalamaktadır. Hazırlanan çalışmanın alana getirdiği yenilikler şu şekilde siralanabilir: (1) Yakın Çă̆'ın zaman-mekânsal tasviri; (2) mekânsal temsilde manipülasyonu engelleyen ve temsilin objektifliğini arttıran ölçeklendirme tekniği; (3) zaman-mekânsal verilerin, analiz birimlerini değiștirmeye imkân sağlayacak şekilde mekânsal ölçek ve zamansal çözünürlük derecelerine göre katmanlı şekilde temsil edilmesi. Bir başka deneysel çalışmayla da yöntemin ve şeritlerin kullanımının ögrrencilerin mekânsal ve senkronik düşünme becerilerini geliştirdiği görülmüştür.
\end{abstract}

Anahtar Kelimeler: Senkronik yaklaşım, senkronik tarih şeridi, histomap, senkronik düşünme, tarih öğretimi.

Abstract:

Historical events and phenomena occur in connection with other events and phenomena within time and space. The diachronic understanding of history has reduced this

\footnotetext{
${ }^{1}$ Gazi Üniversitesi, Türkiye. Orcid ID: 0000-0002-9181-5437

${ }^{2}$ Gazi Üniversitesi, Türkiye. Orcid ID: 0000-0002-6509-4664

*Sorumlu Yazar (Corresponding Author): omurkizil@outlook.com

${ }^{* *} \mathrm{Bu}$ çalışma, 15 Ekim 2020 tarihinde 4. Uluslararası Avrasya Sosyal Bilimler Kongresi’nde sunulan sözlü bildirinin geliştirilmesiyle oluşturulmuştur.
} 
connection between events and phenomena to a causal chain over time. This situation manipulates the perception of history, which is an epistemological structure in nature, by ignoring space. In historiography, the comparative history method has largely eliminated this problem. However, comparative history has not yet seen a systematic effect on the teaching of history subjects. In this study, based on the comparative history and synchronological chart studies; A synchronic approach model that can be used in the teaching of history subjects has been introduced. In this context, synchronological charts that can be used within the scope of the developed model were prepared. Synchronological charts have nearly three centuries of tradition. These materials are one of the limited number of tools that allow for a time-spatial representation of history. Although very old examples are found in Europe and the United States of America, there are few studies in this area in our country. Existing studies have failed to add any innovation to the literature on synchronological charts. In the synchronological charts prepared in Europe and the USA, it is seen that the space factor is manipulated in favor of Europe and the USA. This situation causes the Western Civilization to be represented in a way that it seems "bigger" and more "important" compared to other civilizations. For this reason, the lack of a standard method for the space factor in synchronological charts creates problems in the production of objective works. In this study, a method that solves this problem regarding synchronological charts and provides objective time-spatial representation has been developed and applied. The synchronological chart prepared maps the historical process in Europe, Turkistan, the Middle East and North Africa between 1789-2018 in a time-spatial manner. The innovations brought to the field by the prepared study can be listed as follows: (1) Time-spatial depiction of the Modern Age; (2) scaling technique that prevents manipulation in spatial representation and increases the objectivity of representation; (3) layered representation of time-spatial data according to spatial scale and temporal resolution. In another experimental study, it was seen that the use of the method and the use of synchronological charts improved students' spatial and synchronic thinking skills.

Keywords: Synchronic approach, synchronological charts, histomap, synchronic thinking, history teaching.

\section{GíRis}

Tarih yazımı ve tarihsel düşünme, küreselleşmenin günümüzdeki kadar gelişmediği dönemlerde, dar ölçekli mekânlarda meydana gelen olay ve olgular üzerine şekillenmiştir. Geniş olmayan bir coğrafyaya yönelik gözlemlerle şekillenen tarih anlatısı, diyakronik (art zamanlı) zaman nosyonunun gelişmesinde ve tarih yazımına egemen olmasında etkili olmuştur. Seçilmiş olayların art zamanlı olarak sıralandığı diyakronik tarih anlatısı, geçmiş zamana ilişkin alg1 yanılmalarını da beraberinde getirmektedir (Safran ve Şimşek, 2009). Zincirleme olarak kurulan neden-sonuç bağlantısı, tarihi olay ve olgular arasından bir seçme işlemini zaruri kılmaktadır. Art zamanlı olaylar arasında neden-sonuç kurma eğilimindeki diyakronik tarih anlatısının doğasında bu vardır. Olayların seçiminde izlenen bu tercihler zamanla tek gerçeklik algısına dönüşmekte ve geri kalan tarihi olay ve olguları görünmez kılan kısır bir döngüyü tetiklemektedir (Safran ve Şimşek, 2011).

Ulaşım ve iletişim teknolojilerinin gelişmesine paralel şekilde artan küreselleşme, tarihçinin gözleyebildiği kültür çevrelerinin büyümesine sebep olurken; "karşılaştırmalı tarih" yönteminin gelişimine de gereklilik oluşturmuştur. Zira küreselleşme, milli tarih anlatılarını, bölge ve dünya ölçeğindeki mekânsal ilişsiler bakımından genişletmiştir. Örnek vermek gerekirse, zamansal ve mekânsal hinterlandı geniş olan Türk veya İngiliz tarihi konu edilirken dünyanın birçok bölgesine yayılmış olan başka milletlerin tarihini konu edinmemek mümkün değildir.

Karşılaştırmalı tarih çalışmalarında, tarihsel gerçekliğe ulaşmak üzere birden fazla örnek olay üzerinden olgusal karşılaştırmalar yapılarak, yapısal analizler ortaya konulmaktadır. Gerçekleştirilen analizlerde zaman ve mekândaki değişimler de dikkate alınmaktadır (Tütüncü ve Ünal, 2019). Karşılaştırmalı tarih yöntemiyle incelenen olay ve olgular hem diyakronik hem de senkronik perspektifle karşılaştırılabilmektedir. Diyakronik perspektifin kullanıldığı bir karşılaştırmada, birbirinin ardınca gerçekleşen olay ve olgular; senkronik perspektifin 
kullanıldığı bir karşılaştırmada ise farklı coğrafyalarda eş zamanlı olarak gerçekleşen veya hem zaman hem de mekân açısından farklılık arz etmiş olsalar dahi benzer gelişim aşamalarına sahip olay ve olgular inceleme nesnesi olarak kullanılabilir (Hroch, 2011).

Diyakronik perspektifin yarattığı engel, karşılaştırmalı tarih yönteminin geliştirilmesi ve kullanımıyla birlikte "tarih yazımı" alanında büyük ölçüde giderilmiştir. Ancak karşılaştırmalı tarih, henüz öğretim ortamlarına önemli bir yansımada bulunmamıştır. Karşılaştırmalı yöntemin, tarih konularının öğretimine de uyarlanması suretiyle öğretim süreçlerinde senkronik yaklaşımın tesis edilmesi, söz konusu handikabı ortadan kaldırma hususunda önem taşımaktadır. Ancak bu alanda sınırlı sayıdaki çalışma ya meseleye "karşılaştırmalı tarih" yazımı bağlamında teorik olarak yaklaşmakta ya da hedef, içerik, düşünme becerileri, öğretim materyalleri, öğretim yöntem ve teknikleri ve değerlendirme unsurları açısından zayıf ve meselenin doğasına uygun özgünlüklerden yoksun etkinlik örnekleri üzerine odaklanmaktadır (Kneeshaw, 1988a; Kneeshaw, 1988b). Dolayısıyla araştırma kapsamında ulaşılan alanyazın taramasında, tarih konularının senkronik yaklaşımla öğretimi konusunda büyük bir boşluk dikkat çekmektedir. Konuya tarihsel düşünme becerileri bağlamında temas eden ve tarih öğretiminde senkronik yaklaşımın önemine değinen çalışmalara (Ata, 2006; Ata, 2009; Gaddis, 2002, Kneeshaw, 1988a; Kneeshaw, 1988b; Safran, 2002; Safran ve Şimşek, 2009) rastlansa da senkronik tarih öğretimi üzerine gerçekleştirilen yalnızca bir çalışmaya (Hocaoğlu, 2015) rastlanmıştır. Hocaoğlu'nun (2015) çalışması da farklı bir alanda, üniversite öğrencileri ile gerçekleştirilmiştir. Dolayısıyla senkronik yaklaşım modelini tanıtan ve bu konuda materyaller sunan bu çalışmanın alanyazına katkısı olacağı düşünülmektedir.

Sistematik şekilde ele alınıp tanımlanmasa da senkronik zaman nosyonuyla düşünme, tarih konularının belirli temalar çevresinde ele alınarak öğretiminde kısmen kullanılmaktadır. Örneğin; demokrasi, insan hakları, milliyetçilik, kölelik, feodal düzen, sömürgecilik, sanayileşme vb. konular uluslararası nitelik taşıdıkları için ulusal perspektifi aşan bir mahiyette ele alınmak durumundadır. Osmanlı Devleti'nde ilan edilen Tanzimat ve Meşrutiyet'in, Avrupa ve Dünya'nın diğer bölgelerindeki farklı devletlerde meydana gelen olaylar ve gelişim gösteren fikirlerle bağlantısının ele alınmasının zaruriyeti bu bakımdan değerlendirilebilir. Aynı şekilde Fransız İhtilali'nin bir benzerini eş zamanlı olarak farklı coğrafyalarda görmek mümkün müdür? Fransız İhtilali'ni hazırlayan olay ve olgular diğer devletlerde de gözlenebilmekte miydi? (Yılmaz ve Taşer, 2009, s.5). Bu tarz soruların yanıtlanabilmesi için farklı coğrafyaların tarihine ilişkin malumat sahibi olmak ve sahip olunan bilgiler arasında senkronik düşünme ile çıkarımda bulunmak gerekmektedir. Bu tip bir bilgi birikiminin ortaya çıkmasının güç oluşu, bu bilgileri bir arada bulunduran senkronik tarih şeritlerinin doğuşuna zemin hazırlamıştır. Ancak öncelikle senkronik tarih şeritlerinin kullanımı hususunda da etkili olan senkronik düşünme konusuna değinmekte yarar vardır.

Tarihçiler tarafından karşılaştırmalı tarih çalışmalarında kullanılan senkronik (eş zamanlı) düşünme becerisi, alanyazında yeteri kadar konu edilmemiş ve sistematik şekilde incelenmemiştir. Sınırlı sayıdaki çalışmalardan birinde Şimşek (2006), senkronik düşünmeyle ilgili olarak şunları ifade etmiştir:

Tarihte eşzamanlılık, tarih öğretiminde olduğu gibi tarihsel zaman kavramının öğrencide tam olarak anlaşılması için gerekli ögelerden biridir. Eşzamanlılık, tarihte aynı anda meydana gelmiş iki farklı olayın anlaşılmasını sağlar. Bu yeterlilik, öğrencinin hem kendi bölgesinde hem kendi ülkesinde hem de dünyada veya başka toplumlarda meydana gelmiş tarihsel olayları karşılaştırmalı 
olarak öğrenmesine yardım eder. Bu da tarih öğretimini özcü bir durumdan kurtarmak için birçok firsat sunabilir... Çocuklarda eşzamanlılığın diğer becerilerde olduğu gibi birtakım yeterlilikleri gerektirdiği açıktır (Şimşek, 2006, s.118-119).

Şimşek (2006) senkronizmin, tarihsel zaman kavramının anlaşılması ve tarih öğretimi açısından gerekli bir öge olduğunu ve bazı düşünme yeterlilikleri gerektirdiğini belirtmektedir. Senkronik düşünmeyi doğrudan konu edinen bir diğer isim Gaddis'dir (2002). Gaddis (2002), senkronik düşünmeyi tarihçilerin düşünme becerileri arasında saymaktadır. Buna göre; senkronizm, tarihi olay ve olgular hakkında düşünen bireye, aynı anda birden fazla yerde olma yeteneğini vererek, farklı yerlerde meydana gelen olaylar arasında neden-sonuç ilişkilerinin kurulması, karşılaştırmalar ve analiz işlemlerinin yapılması gibi imkânlar sunan bir düşünme becerisidir.

Yukarıda sunulan ifadelere göre; Şimşek'in (2006), eşzamanlılı̆̆ konvansiyonel zamandaki bir eşzamanlılık olarak algıladığı ve kronoloji becerileri arasında saydığg görülmektedir. Bu anlayışa göre mutlak zamanın metrik sisteminde aynı anda meydana gelen olayların eşzamanlılığından bahsedilmektedir. Bir beceri olarak senkronik düşünme, bu çalışmada Gaddis'de (2002) de görüldüğü şekliyle daha kapsamlı bir olguya işaret etmek için kullanılmıştır. Gaddis (2002), senkronik düşünmeyi Hroch'un (2011) da kullandığı manada konvansiyonel (metrik) zamanın "mutlak” eş zamanlılık sınırından kurtarmaktadır. Buna göre; aynı zaman diliminde meydana gelmese de benzer gelişim süreçleri sergileyen olay ve olgular bu düşünme becerisiyle karşılaştırılabilir ve buradan çeşitli olgularla ilgili çıkarımlarda bulunulabilir.

Yukarıda sayılanlardan başka pek çok çalışma tarihsel zaman tanımlamalarında, tarihin mekân ile ilgili boyutunu ihmal ederek senkronik düşünmenin de ihmal edilmesine sebebiyet vermiştir. National Center for History in the Schools (NCHS, 1996) vb. kurumların tanımladığı tarihsel düşünme becerilerinde ise senkronik düşünme ile doğrudan ilişkili pek çok bileşen farklı düşünme becerilerinin alt boyutları içerisine dağıtılmıştır. Tarih konularının senkronik yaklaşımla öğretimi bu beceri ile yakından ilişkilidir. Bu sebeple, senkronik yaklaşımla öğretim metodunun daha iyi anlaşılabilmesi açısından öncelikle senkronik düşünmenin net bir şekilde tanımlanması ve diğer becerilerle ilişkilerinin ortaya konulması gerekmektedir. Literatürde senkronik yaklaşımın mahiyeti ile ilgili çalışmalara ulaşılamamasının önemli bir sebebi de senkronik düşünme ile ilgili çalışılmamış olmasıdır.

\section{Senkronik Düşünme}

Senkronik düşünme, insanların doğadaki doğal süreçlere yönelik gözlemlerinden dolaylı olarak türemiş bir beceridir. Diğer bir deyişle, İnsan zihninin, varlık dünyası ve doğadaki süreğen devinime yönelik gözlemlerden türettiği epistemolojik yapıların bir ürünü olduğu söylenebilir. Senkronik düşünme, zaman mevhumu üzerine gelişen bir düşünme biçimi olduğu için öncelikle zaman kavramının doğası ve bu kavram ile düşünme becerilerinin ilişkisine bakmak gerekmektedir.

Senkronik düşünmenin doğasını daha ayrıntılı şekilde açıklayabilmek için Şekil-1 oluşturulmuştur. 

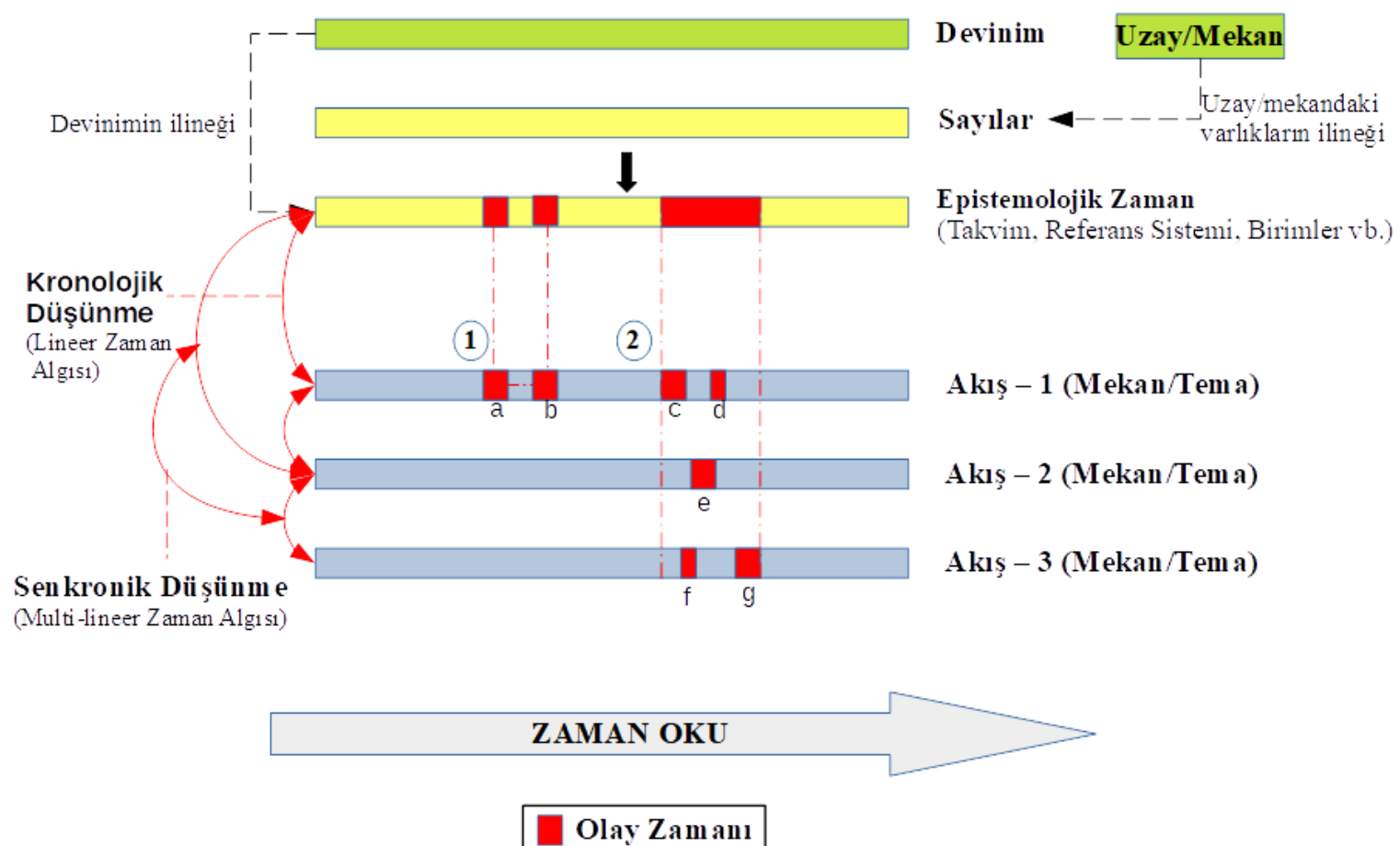

Şekil 1. Senkronik (Eş Zamanl1) Düşünme

Şekil 1 incelendiğinde, senkronik düşünmenin (uzay/mekân da dâhil edildiğinde) yedi farklı şeridin arasındaki ilişkiler bağlamında açıklandığı görülmektedir. Şekil 1'deki şeritlerden yalnızca "uzay/mekân" ve "devinim" olguları ontolojik bir nitelik taşımaktadır. Buna göre "uzay/mekân" ile kastedilen mikro ölçekten makro ölçeğe kadar varlık âlemi iken "devinim" ile kastedilen bu varlık âleminin akış ve temaşa içerisindeki varoluşudur. Şekil 1'deki diğer unsurlar ise insan zihninin bu iki yapıdan türettiği epistemolojik inşa ürünleridir.

"Sayılar" insan zihninin uzay/mekândaki varlıklardan ilinek olarak türettiği epistemolojik bir yapıdır. Uzay/mekândaki varlıklar/nesneler veya o nesneleri sayacak bir zihin olmadığ1 takdirde sayılardan bahsedilemez. "Epistemolojik zaman" da benzer şekilde "devinim"in ilineği olarak insan zihni tarafından inşa edilmiş epistemolojik bir yapı ve referans sistemidir. "Sayılar"'1n da eklenmesiyle oluşturulan takvim sistemleri, zaman birimleri (gün, ay, yıl vb.) ve kavramları bahsi geçen "epistemolojik zaman"ın içerisinde değerlendirilebilecek unsurlardandir.

Zaman mevhumunun, nesnelerden ve hareketten ayrı tutulamayan bir olgu olması sebebiyle, devinimin ilineği olarak nitelendirilmesinde Aristoteles (2017), İbni Rüşd (2018), Bergson (2017) ve Köktürk'ün (2017) bu konudaki düşünceleri etkili olmuştur. Sayıların da uzay/mekândaki varlıkların ilineği olarak ortaya çıktığı bilindiği üzere daha önceden Aristoteles (2017) tarafından dile getirilmiştir. Aristoteles aynı zamanda ilinek sözcügünü terim olarak kullanan ilk kişidir. İlinek, bir varlığa veya olguya bağlı olan ve o varlık/olgu olmadan kendisi var olamayan şey olarak tanımlanabilir. Dolayısıyla ilinek bir tözü (varlığı/olguyu) gerektiren taşıyıcı şey, bir başka deyişle tözün niteliği olarak tarif edilebilir. Dolayısıyla sayılar doğadaki varlıklar olmadan; zaman ise doğadaki süreğen devinim, akış ve temaşa olmadan var olamayacak epistemolojik yapılar olup; bu tözlerden üretilen ilinekler olarak nitelendirilmiştir. 
Buraya kadar bahsi geçen yapılar, zaman ile ilgili her düşünme becerisinin temelini teşkil etmektedir. Dolayısıyla sadece senkronik düşünme değil kronolojik ve tarihsel düşünme gibi beceriler için de aynı temelden bahsedilebilir. Zira insanlığın zaman ile ilgili ürettiği her olgu, kendisi de insan zihninin bir inşası olan "epistemolojik zaman" kavramı üzerine temellendirilmiştir. Epistemolojik zaman, hem kendisi insan düşüncesinin bir ürünü olmakta hem de ilgili düşünme becerileri için bir araç teşkil etmektedir.

Epistemolojik zaman inşası, artan sosyal organizasyon düzeyine bağlı olarak önem kazanan bir mahiyette, meydana gelen veya gelecek olay ve olguların düzenlenmesi açısından bir referans sistemi sunmaktadır. Örneğin; Şekil 1'de "Akış 1" şeridindeki "a" olayının, diğer olaylara göre bulunduğu zamansal konumun referans sistemi (takvim) ile işaretlenmesi (örn. "a" olayı 29 Ekim 1923'te gerçekleşmiştir) bu duruma örnek teşkil edebilir.

Senkronik düşünmenin doğasını anlayabilmek için diğer şeritlerin ne anlama geldiğine de bakmak gerekmektedir. "Akış 1", “Akış 2", “Akış 3" șeritlerinin her biri farklı bir coğrafya veya konudaki zamansal akış formlarını temsil etmektedir. Örneğin coğrafi açıdan düşünülerek; “Akış - 1" Türkiye tarihi, "Akış - 2" İngiltere tarihi ve "Akış -3" İran tarihinde meydana gelen olay ve olguları barındıran tarih şeritleri gibi düşünülebilir. Bu şeritler mekân yerine farklı temaları da temsil edecek şekilde düşünülebilir. Örneğin; eğitim, siyaset, ulaşım vb. alanlardaki gelişmeler gibi.

Şekil 1, senkronik düşünmenin yanında kronolojik düşünmenin nasıl gerçekleştiğini de göstermektedir. Senkronik düşünmenin tam olarak anlaş1labilmesi açısından kronolojik düşünme ile farklarının ortaya konulmasının yararlı olacağı düşünüldüğünden öncelikle kronolojik düşünme örneği incelenmelidir. Şekil 1'de yer alan "1" numaralı örnek, bu anlayışın 1şığında kronolojik düşünmeyi açıklamak için hazırlanmıştır. "1" numaralı örnek incelendiğinde; aynı akış konfigürasyonu (Akış 1) içerisinde bulunan iki (a ve b olayları) veya daha fazla sayıda olayın, zamansal referans çerçevesi (epistemolojik zaman) ile konumlandırılarak zamansal niteliklerine göre artzamanlı (diyakronik) perspektifle karşılaştırılmasını içermektedir. Bu şekilde gerçekleşen bir düşünme süreci neticesinde, Şekil 1 'deki "a" ve "b" olaylarının artzamanlı olaylar oldukları, "b" olayının "a" olayından sonra gerçekleştiği gibi bilgiler yapılandırılabilir. Olaylar arasında neden-sonuç ilişkisi varsa, öncelik-sonralık bakımından taşıdıkları özellikler de göz önünde bulundurularak bu konuda değerlendirmeler yapılmasına hizmet edebilir. Mevcut öğretim programları ve ders kitapları göz önünde bulundurulduğunda büyük ölçüde bu diyakronik perspektife göre tasarlandıkları görülmektedir.

Senkronik düşünme, kronolojik düşünmeden farklı olarak birden fazla mekân veya temadaki akış (Akış 1-2-3 vb.) içerisinde meydana gelen olayların zaman-mekânsal konfigürasyonları ile ilgili değerlendirmeleri barındırmaktadır. Burada kronolojik düşünmeye göre en büyük farklılı̆̆ın, tarihin mekân faktörünün ve farklı mekânsal/tematik bağlamların devreye girmesi olduğu söylenebilir. Örnek üzerinden açıklamak gerekirse; "Akış 1" içerisinde yer alan "c" ve "d"; "Akış 2" içerisindeki "e" ve "Akış 3"teki "f" ve "g" olaylarının, zamansal referans sistemindeki (takvim) konumları ve bünyelerinde barındırdıkları mekânsal veya tematik özellikler de göz önünde bulundurularak tarihsel bir bilgi veya bağlamın yapılandırılmasında karşılaştırmalı olarak kullanılması bir senkronik düşünme performansı örneği olarak değerlendirilebilir. Karşılaştırmalı tarih yöntemini kullanan tarihçilerin sergiledikleri bilişsel performans da büyük ölçüde bu şekilde gerçekleşmektedir. 
Tarihi olay ve olguların, arka planlarında yatan unsurlarla bir bağlam içerisinde değerlendirilebilmesi için senkronik düşünme elzemdir. Ancak insanların bilişsel sistemi, diyakronik (art zamanlı) perspektifle düşünme açısından daha elverişli olup senkronik düşünme açısından bir handikap yaratmaktadır. $\mathrm{Bu}$ handikabı ortadan kaldırabilecek veya zayıflatabilecek bir unsur olarak senkronik düşünmeyi geliştirebilecek nitelikte tecrübeler/yaşantılar ön plana çıkmaktadır. Tarih konularının öğrenimi/öğretimi ile ilgili düşünme becerilerinin kullanılabilmesi için tarih ile ilgili bir içeriğe ihtiyaç vardır. Senkronik düşünme becerisi açısından da aynı durum geçerlidir. Fakat kullanılmakta olan öğretim programlarının içerik ve yöntem boyutları incelendiğinde; öğrencilerin senkronik düşünmesini gerektirecek ve geliştirecek, bu konuda yaşantı sağlayacak herhangi bir içeriği ve yöntemi barındırmadığı anlaşılmaktadır. Şimşek (2006), öğretmenlerin bu konu üzerinde hiç durmamaları ve ders kitaplarının bu anlayışa göre düzenlenmemesi açısından söz konusu duruma dikkat çekmiş ve öğrencilerin bu tip sebeplerden dolayı senkronizm ile ilgili ifadeleri anlamakta sorunlar yaşadıklarını belirtmiştir (s.247). Dolayısıyla, öğretim ortamlarının öğrencilere yeteri kadar tecrübe imkânı sağlamaması, senkronik düşünme becerilerinin gelişimini engellemektedir. $\mathrm{Bu}$ sorunu çözebilmek açısından öğretim programlarında ve ortamlarında tarih konularının öğretimine yönelik senkronik yaklaşımın yerleşmesi önem kazanmaktadır. Aksi takdirde tarih konularının öğretimi, günümüzde de olduğu gibi, seçilmiş olay ve olguların artzamanlı bir neden-sonuç zinciri içerisinde sergilenmesine indirgenmektedir. $\mathrm{Bu}$ durum ise tarihi olay ve olguların hakiki bağlamları içerisinde değerlendirilmesini güçleştirmektedir.

\section{Araştırmanın Amact}

Alan yazında karşılaştırmalı tarih yöntemi ve tarih konularının öğretiminde senkronik yaklaşımın önemine değinen çalışmalara rastlansa da bu tip bir öğretimin ne şekilde gerçekleştirileceği hususunda büyük bir boşluk bulunmaktadır. Bu çalışmanın amacı alan yazındaki karşılaştırmalı tarih ve senkronik tarih şeridi çalışmalarından hareketle tarih konularının öğretiminde kullanılabilecek bir senkronik yaklaşım modeli ortaya koymaktır. $\mathrm{Bu}$ bağlamda geliştirilen model kapsamında kullanılabilecek senkronik tarih şeritleri hazırlanmıştır.

\section{YÖNTEM}

Çalışmada nitel araştırma yöntemlerinden "kuram oluşturma" yöntemi kullanılmıştır. Bu yaklaşımda özel bir kavramsal çerçeve veya kuramdan hareket etmek yerine, toplanan verilerle kuram oluşturma sürecine odaklanılmaktadır. Bu açıdan bakıldığında kuram oluşturmanın en belirgin özelliği olarak "tümevarımsal" yaklaşım dikkat çekmektedir. Bu süreçte araştırmacı; kavramlar, temalar ve bunların ilişkilerine yönelik denenceler geliştirir ve bu denencelerin açıklanmasına (teyit etme veya reddetme) yardımcı olacak verilere ulaşmaya çalışır. Sonuçta ulaşılan kavramlar ve temalar, araştırma konusuna ilişkin anlamlı bir açıklama sunar (Yıldırım ve Şimşek, 2013). Tarih konularının senkronik yaklaşımla öğretimi ve senkronik düşünme konusunda daha önceden herhangi bir çalışma gerçekleştirilmemiş olması, söz konusu unsurların boyutlarının ve bileşenlerinin ortaya koyulması amacıyla kuram oluşturma yaklaşımının benimsenmesinde etkili olmuştur.

\section{Örneklem}

Çalışmada amaçlı örnekleme yöntemlerinden ölçüt örnekleme tekniği kullanılmıştır. Bu bağlamda, zaman ve mekân boyutlarına yer veren yatay veya dikey doğrultuda zamanın akışını doğrusal şekilde temsil eden klasik çalışmalar tercih edilmiştir. Bu ölçütleri karşılayan ve 
çalışma kapsamında incelemeye alınan senkronik tarih şeridi ve ilgili çalışmalar; Bruyere (1750), Jefferys (1750), Priestley (1769), Sparks (1931), Adams (2007) ve Rosenberg ve Grafton (2010) tarafından gerçekleştirilen ve klasik olarak nitelendirilebilecek çalışmalardır.

\section{Veri Toplama Teknikleri}

Seçilen örneklem kapsamında ele alınan senkronik tarih şeridi çalışmalarının incelenmesi ve ölçekli senkronik tarih şeridinin oluşturulması aşamasında doküman incelemesi tekniği ile veri toplanmıştır. Doküman analizi, yazılı belgelerin içeriğini titizlikle ve sistematik olarak analiz etmek için kullanılan bir nitel araştırma yöntemidir (Wach, 2013).

\section{Verilerin Analizi}

Seçilmiş senkronik tarih şeridi çalışmalarından doküman inceleme tekniği ile toplanan veriler üzerinde içerik analizi gerçekleştirilmiştir. İçerik analizinde yapılan işlem, elde edilen verilerin birbirine benzeyenlerini belirli kavram ve temalar altında toplayarak bir araya getirmek ve okuyucunun anlayacağı biçimde düzenleyerek yorumlamaktır (Yıldırım ve Şimşek, 2013, s.259). İçerik analizi dört aşamadan meydana gelmektedir: Verilerin kodlanması, temaların bulunmas1, verilerin kodlara ve temalara göre yeniden düzenlenmesi ve tanımlanmas1, bulguların yorumlanması (Yıldırım ve Şimşek, 2013, s.260).

\section{BULGULAR, YORUM VE TARTIŞMA}

İçerik analizi neticesinde ulaşılan temalar bakımından, senkronik yaklaşım modelinin odak noktasında "ölçek" ve "çözünürlük" kavramlarının yer aldığı belirlenmiştir. Konuya coğrafi açıdan yaklaşılacak olursa; bazı olay ve olgular yalnızca geniş alanlar çerçevesinde kavranabiliyorken; farklı nitelikteki başka olay ve olgular yalnızca çok dar bir çevredeki gözlemlerle açıklanabilir. İncelenen tarihi olay ve olguları anlamlandırabilmek için sergilenen "ölçeğin kayması" olarak isimlendirilen zihinsel performans, analiz düzeyindeki ve kavramsallaştırmadaki bir değişiklik anlamına gelmektedir (Lacoste, 2014, s.95). Benzer bir durum, coğrafi olanla karşılaştırılabilir bir nitelikte tarihle ilgili olay ve olgular için de geçerlidir. Örneğin; 14 Temmuz 1789'da gerçekleşen Fransız İhtilali'ni tarihsel bağlamı içerisinde değerlendirebilmek için; bir gün, bir hafta veya aylar öncesinde neler olduğunun değerlendirilmesi veya bu değerlendirmelerin çerçevesinin çok daha uzun zaman dilimlerine yayılması (önceki bir yıl, on yıl veya eski rejimin yıkılmasını önceleyen üç asır) arasında önemli bir fark olacağı öngörülebilir (Lacoste, 2014, s.97).

Ölçek, coğrafi olarak da kronolojik olarak da tarihte yeni bir konu değildir. Fakat son dönemde ulus üstü tarih yazımı ile ilgilenen tarihçiler tarafından metodolojik inceleme altına alınmış (Alcalde, 2018, s.558) güncelliğini koruyan bir temadır. Gaddis (2002) ve Lacoste'un (2014) "ölçek" benzetmesi, bu çalışmada açıklanan senkronik yaklaşım modelinde de kullanılmıştır. Ancak mekânsal ve zamansal ölçekler ile ilgili bir karışıklığa mahal vermemek için zaman boyutu ile ilgili ölçeklendirme konusunda "çözünürlük" kavramı kullanılmıştır. Olay ve olguların zamansal özellikleri üzerine düşünürken, analiz birimi olarak kullanılan zaman birimlerinin (ay, yıl, asır, milenyum vb.) uzunluğuna göre çözünürlüğün derecesi de değişmektedir.

Senkronik düşünme sürecinde, mekânsal ölçek ve zamansal çözünürlük arasında doğrusal bir ilişkiden bahsedilebilir. Mekânsal ölçek büyüdükçe, zamansal çözünürlük genelde artmaktadır. Aynı şekilde, zamansal çözünürlük arttıkça da mekânsal ölçek büyümektedir. Üzerine düşünülmekte olan olayın/olgunun içerisinde bulunduğu konfigürasyon, bu durumun boyutunu 
ve derecesini etkilemektedir. Buna göre dar/orta/geniş ölçekli olarak isimlendirilen zamanmekânsal alanın ölçeği ve çözünürlüğü de göreceli olarak ara değerler alabilir. Örneğin; tarihi olayın özelliğine göre dar ölçek, bir köy veya şehirdeki haftalık bir periyod olabilir veya olayın/olgunun içerisinde bulunduğu dokuya bağlı olarak bir cephedeki veya bir ülkedeki aylık periyoda da tekabül edebilir.

Senkronik düşünmenin, farklı niteliklere sahip tarihi olay ve olgular üzerindeki tatbikinin daha iyi idrak edilebilmesi açısından mekânsal ölçek ve zamansal çözünürlük özelliklerine göre kategorize edilen katmanlı zaman-mekânsal sınıflandırması aşağıda sunulmuştur:

1) Dar Ölçekli Zaman-Mekânsal Senkronizasyon Katmanı

a) Arttırılmış zamansal çözünürlük ve büyütülmüş mekânsal ölçek

b) Düşürülmüş zamansal çözünürlük ve küçültülmüş mekânsal ölçek

2) Orta Ölçekli Zaman-Mekânsal Senkronizasyon Katmanı

a) Arttırılmış zamansal çözünürlük ve büyütülmüş mekânsal ölçek

b) Düşürülmüş zamansal çözünürlük ve küçültülmüş mekânsal ölçek

3) Geniş Ölçekli Zaman-Mekânsal Senkronizasyon Katmanı

a) Arttırılmış zamansal çözünürlük ve büyütülmüş mekânsal ölçek

b) Düşürülmüş zamansal çözünürlük ve küçültülmüş mekânsal ölçek.

Katmanlar arası geçişler, zihinsel bir performansa işaret etmektedir. Bu zihinsel performansta, mekânsal ölçeğin ve zamansal çözünürlüğün kayması esastır. Bu katmanların sayısı yukarıda sunulduğu şekilde kesin ve net değildir. Olay ve olguların mahiyetine göre bu katmanların sayısı artabilir veya düşebilir. Yukarıda sunulan senkronik düşünme katmanlarına, Türk İstiklal Harbi kapsamındaki tarihi olaylardan şu örnekler sunulabilir:

1. Dar Ölçekli Zaman-Mekânsal Senkronizasyon Katmanı: Batı Cephesi. I. İnönü Savaşı (9 11 Ocak 1921) ve Çerkez Ethem isyanı (27 Aralık 1920- 23 Ocak 1921) üzerine gerçekleştirilen bir senkronik düşünme sürecinde Batı Anadolu coğrafyasında gerçekleşen eşzamanlı olaylar düşünme nesnesi olarak alınmıştır. Bu örnekte zamansal çözünürlük, "günler" ile tarif edilebilir.

2. Orta Ölçekli Zaman-Mekânsal Senkronizasyon Katmanı: İstiklal Harbi. Türk İstiklal Harbi'nin üç cephesi (Batı, Güney ve Doğu) üzerine gerçekleştirilen bir senkronik düşünme sürecinde, ilk katmandakine oranla daha geniş bir coğrafyada (orta ölçekli) gerçekleşen eşzamanlı olaylar düşünme nesnesi olarak alınmıştır. Bu örnekteki coğrafya ölçeğin küçülmesine bağlı olarak daha geniş olsa da zamansal çözünürlük, ilk katmandakine göre daha düşüktür; burada zaman birimi olarak "günler" önemini yitirirken "aylar" ve "yıllar" kullanılabilir.

3. Geniş Ölçekli Zaman-Mekânsal Senkronizasyon Katmanı: İstiklal Harbi’nin uluslararası hinterlandı. Türk İstiklal Harbi, İtalya'daki siyasi iç karışıklıklar, Versay sonrası askeri ve ekonomik açıdan güçlü bir Almanya'nın varlığı ve İrlanda Kurtuluş Savaşı üzerine gerçekleştirilen bir senkronik düşünme sürecinde ilk iki katmandakine göre daha geniş bir coğrafyada (geniş ölçekli) gerçekleşen eşzamanlı olaylar düşünme nesnesi olarak alınmıştır. Bu örnekteki coğrafya diğerlerine göre çok daha büyük olsa da zamansal çözünürlük, onlara göre biraz daha azalmıştır. Burada zaman birimi olarak daha çok "yıllar"'ın kullanımından bahsedilebilir. 
Tarihi olay ve olgular üzerine, bu katmanlardan birisi içerisinde kalınarak da senkronik düşünmek suretiyle analiz gerçekleştirilebilir. Ancak daha üst düzey sentezlere ulaşabilmek için katmanlar arası geçişler de mümkündür. Burada Gaddis'in (2002) deyimiyle, zihinsel bir performans olarak ölçeğin kayma kapasitesi önem kazanmaktadır.

Tarih anlatılarında, asırlardır kullanılan bir geleneğe uygun şekilde, analiz birimi olarak ulus devlet ele alınmaktadır. Karşılaştırmalı tarih yönteminin ortaya çıkışı, ulus ötesi analiz birimlerini de gündeme getirmiştir. Günümüzde artık mikro tarihten kıtalar ve okyanuslar gibi ulus üstü birimlere, hatta dünya gibi çok büyük mekânsal konfigürasyonlara kadar ölçeklerde meydana gelen bir değişim söz konusudur (Alcalde, 2018). Bu durumun tarih konularının öğretimine de yansıtılması hususunda, ölçeği zihinde kaydırmayı mümkün kılan senkronik düşünme ve senkronik yaklaşım modeli önem kazanmaktadır. Aşağıda senkronik düşünme becerisini geliştirmek üzere senkronik yaklaşım modelinde kullanılabilecek öğretim materyalleri ile ilgili bilgi verilmiş ve bu model doğrultusunda hazırlanan özgün bir çalışma sunulmuştur.

\section{Senkronik Yaklaşım Modeli Kapsamında Kullanılabilecek Öğretim Materyalleri}

Tarih konularının senkronik yaklaşımla öğretimi ve senkronik düşünme becerisinin geliştirilmesi hususunda bazı özel öğretim materyallerinin işe koşulması gerekmektedir. Bu iş için kullanılabilecek öğretim materyallerini, insan bilişsel sistemi ile ilişkileri içerisinde ele almak, konunun zaruriyetinin daha iyi anlaşılması açısından önem arz etmektedir.

Bilişsel sistem içerisinde, bilginin işlenmesi ve yapılandırılması konusunda çalışma belleği olarak da isimlendirilen kısa süreli bellek (KSB) başrolü üstlenmektedir. Bilgiler taşıdıkları niteliklere göre KSB'de bulunan iki farklı modülden birinde işlenmektedir. Bu iki modül, "sözelleştirme döngüsü" ve "görsel-mekânsal alan" olarak adlandırılmaktadır (Solso, MacLin ve MacLin, 2018, s.204). Sözel veriler, "sözelleştirme döngüsü” modülünde işlenirken; görsel ve mekânsal nitelik taşıyan veriler "görsel-mekânsal alan"da işlenmektedir. Sözcükler/kavramlar ve dolayısıyla "sözelleştirme döngüsü" yanıltıcı bir şekilde, düşünme sürecinin temelinde yatıyor gibi görünse de üretken düşünme bakımından alanyazın bunun aksini göstermektedir. Örneğin; Arnheim (2015), kavramların düşünme sürecindeki değerini, ancak düşünme sürecine kılavuzluk eden görsel imgelere sağlayabildikleri yardımla sınırlamıştır (s.259). Einstein da düşünme sürecindeki görsel-mekânsal alanın önemi konusunda benzer bir görüş bildirmiştir: "Bana özgü yetenek, matematiksel hesaplamalardan gelmiyor; etki, olasılık ve sonuçları görselleştirmekte yatıyor” (Pinker, 2018, s.331).

Retorik ifadelerin yerine işaret ve sembollerin kullanılması hususunda da benzer bir durumla karşılaşılmaktadır. Mazur (2018) matematik alanından verdiği örneklerde sözcüklerin yerine sembollerin kullanılmasının, zihnin yazılı sözcüklerce sürüklendiği anlam karmaşalarından kurtulmasını sağladığını ifade etmektedir (s.119). Sözel ifadeleri kullanarak cebir yapan matematikçilerin, bugün matematiğin sembolik dilini kullanan matematikçilerin rahatlikla gördüklerini asırlar boyunca fark edememiş olmaları, bu konuda ilgi çekici bir örnek sunmaktadır (Mazur, 2018, s.150).

Bilişsel psikoloji alanındaki çalışmalar, karışık mantık problemlerinin çözümünde görselmekânsal düşünmenin ürünleri olan şemaların ve imgelemenin yararlılığını kanıtlamıştır (Solso vd., 2018, s.515). Koslyn'in (1983) araştırması, çocukların depolanmış hazır cevapları yoksa soruyu cevaplamak için imgelemeyi kullandıklarını göstermektedir (akt. Solso vd., 2018, s.491492). Hızlı bir şekilde gerçekleşen akıl yürütme düşünürler, bilim insanları ve sanatçılar 
tarafından da gerçekleştirildiği gibi ancak görsel duyu girdilerinin bilişsel sistem içerisinde yine aynı formatta (görsel-mekânsal formda) işlenmesiyle gerçekleşmektedir. İnsan zihinlerinin ürettiği büyük fikirler, zihnin duyular dünyasıyla sürekli yürütmekte olduğu bu ilişkiden doğmaktadır (Arnheim, 2015, s.233).

Görsel ve mekânsal formdaki bu tip bir düşünme süreci, yapılandırılan bilgilerin de yine aynı formatta temsil edilebilmesine imkân sağlamaktadır. Çizim, grafik, resim, tablo şeklinde yapılandırılan ve temsil edilen bilgiler buna örnek olarak verilebilir. Ancak bu araçlar yapılandırılmış ve bitmiş düşünceleri görünür modellerle sunma araçları değildir. Bu temsil araçları, çeşitli problemlerin çözüm süreçlerinde mekânsal düşünmeye de katkı sağlamakta ve hatta bu tip bir düşünmenin bizzat kendisi olmaktadırlar (Arnheim, 2015, s.151).

Görsel-mekânsal formdaki bu düşünme süreci, hem duyu girdilerinin bu formda işlenmesini hem de üretilen bilginin yine aynı formda (görsel-mekânsal) temsilini mümkün kılmaktadır. Üretilen bu temsil araçları da (çizimler, resimler, grafikler vb. diğer ürünler) sadece bitmiş düşünceleri görülür modellere çevirme aracı değildir. Bu araçlar, ayrıca problemlerin çözümü sürecinde mekânsal düşünmeye de katkıda bulunmakta; hatta bu tip bir düşünmenin kendisi olmaktadırlar (Arnheim, 2015, s.151). Bu tip araçlar, pek çok alanda olduğu gibi sosyal bilim disiplinlerinde de benzer işlevleriyle önemli bir yer tutmuştur. Mekânsal düşünmenin, bu yönüyle tarih konularının öğretimi ve zaman kavramı hususunda da bu konular üzerine düşünmeyi kolaylaştıran pek çok firsat alanı açtı̆̆ı söylenebilir. Senkronik tarih şeritleri, bu alanlardan birisidir.

Aydınlanma Çağı ile birlikte başat zaman algısı olarak ortaya çıkan çizgisel zaman, en iyi şekilde zaman şeridi ile temsil edilmektedir. Çoklu çizgisel zaman algısının mekânsal temsili olan senkronik tarih şeritleri, zaman-mekânsal nitelik taşıyan verilerin sunumu açısından güçlü özelliklere sahiptir. Harms ve Lettow (2007), senkronik tarih şeritlerinin bu yönüne dikkat çekerek, çocuklarda zaman ve kronoloji kavramlarının geliştirilmesinde faydalanılabilecek bir araç olarak "çoklu zaman şeridi" (multiple time line) söylemini tercih etmiş ve bu materyalin çeşitli kaynaklardan gelen bilgileri sentezleyerek sunabileceğini belirtmişlerdir.

Senkronik tarih şeritlerinde görselleştirilen zamana bağl1 mekânsal veri (zaman-mekânsal) zaman, mekân ve öznitelik olmak üzere üç temel bileşenden meydana gelmektedir (Mullaw, 2008). Zamana bağlı mekânsal görselleştirme (spatiotemporal visualization), zaman-mekânsal süreç, değişim ya da olayların incelenmesini mümkün kılarak senkronik düşünme konusunda önemli bir araç teşkil etmekte olup; son yıllarda oldukça popüler hale gelmiştir (Kraak ve Ormeling, 2011'den akt. Keskin vd., 2015).

Zaman-mekânsal verilerin görselleştirilmesinde en yaygın kullanılan görselleştirme yöntemleri statik haritalar, animasyonlar, zaman-mekân küpü (ZMK- space-time cube) ve senkronik zaman/tarih şeritleridir. Bu sayılan yöntemlere, sosyal bilgiler ve tarih konularının öğretimi perspektifinden bakıldığında; tek sabit harita (şekil 2-a) kullanım geleneğinin çok eski dönemlerden beri devam ettiği söylenebilir. Tarih haritalarının öğretim süreçlerinde kullanımı, bölgesel çatışmaların incelenmesi, bir ülkenin coğrafi genişlemesinin keşfi ve toprak eklenmesinin bir ülkenin büyümesi üzerindeki etkilerini anlama gibi konularda öğrencilere yardımcı olmaktadır (Şengül Bircan ve Safran, 2013, s.466). Ancak bu materyallerle yalnızca anlık bir zamansal gösterim yapılabilmektedir. Bu handikabı aşmak için çoklu (ardışık) sabit haritalar bir araya getirilerek, tarihi olaylar zaman akışı içerisinde farklı materyaller üzerinde görselleştirilebilir (şekil 2-b). Bu şekilde haritaların konu edindiği dönemlere ilişkin zamansal 
değişim, mekândaki/coğrafyadaki değişim ile eş zamanlı şekilde takip edilebilir. Ancak bu yöntemin handikabı da çok sayıda haritayı bir arada kullanmak zorunda bırakmasıdır. Bu durum öğretim sürecini karmaşık hale getirebilmekte ve algılamayı güçleştirmektedir (Keskin vd. 2015).

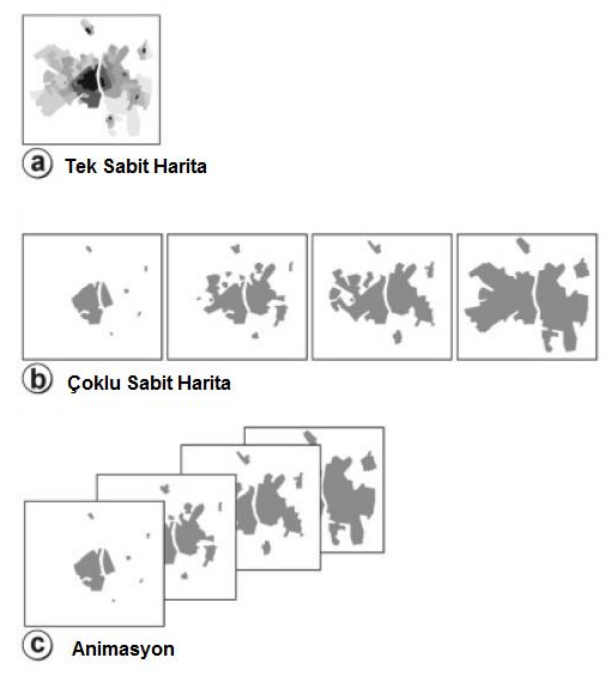

Şekil 2. Zaman-Mekânsal Verilerin Görselleştirilmesinde Kullanılan Yaygın Teknikler. Şekil 2'nin oluşturulmasında "Clemens, L. (2014). The Effectiveness of Uncertainty Visualization in a "Coordinated Multiple View" Environment Using a Temporal Dataset (Casestudy) (Yayımlanmamış Yüksek Lisans Tezi). Dresden: Technische Universität Dresden, s.15" kaynağından yararlanılmıştır.

Zaman-mekânsal nitelikteki verilerin görselleştirilmesi amacıyla kullanılabilecek bir diğer yaygın yöntem ise animasyonlardır (şekil 2-c). Animasyonlar, tek bir çerçevede çok sayıda anlık gösterimin ardı ardına sergilenmesine imkân tanımaktadır. Burada değişim, mekânsal diziden değil bizzat haritanın kendi hareketiyle algılanabilmektedir (Keskin vd., 2015).

Zaman-mekânsal verilerin görselleştirilmesinde kullanılan bir diğer güçlü teknik ise zamanmekân küpüdür. Zaman-mekân küpünün haritalar ile güçlü dinamik bağlantılara sahip olması, bu tekniğin ayırt edici önemli bir özelliğidir (Andrienko vd., 2003, s.1981). Zhao ve arkadaşları (2013), zaman-mekân küplerinin çok sayıdaki görselleştirme yönteminin verilerini tek seferde dinamik bir şekilde gösterebilme kabiliyetine sahip olduğunu belirtmişlerdir (akt. Windhager, 2013).

Hägerstrand'1n (1982) geliştirdiği zaman-mekân küpü, üç boyutlu uzayda gerçekleşen olayların, iki boyutlu bir düzleme iz düşürülmesi mantığına dayanmaktadır. Zaman-mekân küpü, zihinde gerçekten bir küp şeklinde canlandırıldığında; küpün tabanı (x-y eksenleri) mekânı/coğrafyayı, yüksekliği (z ekseni) ise zamanı temsil etmektedir. Zaman-mekân küpünün bu eksenleri arasında zamana bağlı olarak değişim gösteren veya mekânlar arasında harekete sebep olan olay ve olguların temsil edildiği zaman-mekân yolları görselleştirilmektedir.

Çalışmanın bundan sonraki kısmında ise zaman-mekânsal nitelikteki verilerin görselleştirilmesinde kullanılabilecek güçlü bir yöntem olarak (senkronik yaklaşımla öğretim modeli kapsamında da kullanılabilecek) senkronik tarih şeritleri konu edilmiştir. 


\section{Senkronik Tarih Şeritleri}

Dönmez ve Yazıcı (2008), T.C. İnkılap Tarihi ve Atatürkçülük dersinin öğretiminde kullanılabilecek araç-gereçlere yönelik gerçekleştirdikleri sınıflandırmada, zaman şeritlerine "soyut görsel semboller" içerisinde yer vermişlerdir. Dönmez ve Yazıcı (2008), alanyazında sıklıkla karşılaşılan "zaman şeridi- tarih şeridi” kargaşasını da konu edinmişlerdir. Getirilen açıklamaya göre; zaman şeritleri dar zamanlı olaylar için kullanılırken, daha uzun zaman dilimlerini veya bütün bir tarihi tek bir gösterimde sergileyen şeritlere tarih şeridi denildiğinin üzerinde durulmuştur. Bu çalışmada da "tarih şeridi" kavramı, bu anlamda kullanılmaktadır.

Daha önceden de belirtildiği üzere, olay ve olguların eş zamanlı temsili ancak görsel formatta mümkün olmaktadır. Zira Arnheim'ın (2015) da belirttiği üzere resimsel imgeler, kendilerini eşzamanlılık içerisinde bir bütün olarak sunmaktadır (s.278). Bu sebeple senkronik tarih şeritleri, bu konuda önemli avantajlar barındırmaktadır. Çok sayıda tarihçi ve eğitimci, bu durumu erken sayılabilecek bir dönemde fark etmiş ve bu konuda çalışmışlardır. Devletlerin, olguların ve olayların eşzamanlı sunumunu gösteren senkronik tarih şeritleri ile ilgili çalışmaların, 18. yüzyıldan itibaren güçlü bir şekilde ortaya çıkışı bu duruma örnek olarak gösterilebilir. Priestley'in (1769) bu konudaki ifadeleri, durumu açık bir şekilde göstermektedir:

Senkronik tarih şeridini kastederek) bu tür bir cetvelin başlıca yararı, tarihi öğrenmek için mükemmel bir materyal olmasıdır. Tarihi süreç içerisinde varlık göstermiş bütün önemli imparatorlukların yükseliş, ilerleme, yayılma dönemleri ve bugünkü durumları bir daha silinmeyecek bir biçimde zihne kazınır. İnsan yatay bir çizgi üzerinde, bir ülkede meydana gelen tüm inkılapları ve o anda kimin yönetimde olduğunu, okumaya nazaran çok daha kısa bir süre içerisinde görebilir. Şunu kesinlikle söyleyebilirim ki, haftalarca kitap okumak yerine bu cetvelin bir saat incelenmesiyle tarih çok daha kolay bir şekilde öğrenilebilir (s.11-12).

İlk örnekler çoğunlukla Avrupa'da ve Amerika Birleşik Devletleri'nde ortaya çıkmıştır (Bruyere, 1750; Jefferys, 1750; Priestley, 1769; Sparks, 1931; Adams, 2007; Rosenberg ve Grafton, 2010). Ancak Osmanlı Devleti'nde de tarih konularının öğretiminde senkronik yaklaşımın gerekliliği ve senkronik tarih şeritlerinin kullanımı konularının dikkat çektiği görülmektedir. Örneğin II. Meşrutiyet yıllarında, Ali Reşat Bey'in yazmış olduğu "Okullarda Tarih Dersi" başlıklı makalede, "bir memlekette meydana gelen tarihi olayı ve aynı vakitlerde diğer memleketlerde meydana gelmiş olan olayları zamanlarına uygun olarak gösteren tablolar, coğrafya krokileri, istatistik ve grafik levhaları"nın kullanımından bahsedildiği; "öğrenciye, çeşitli toplumların karşılaştırılmasını içeren, tarihi olaylar arasındaki ilişkiyi gösteren ve açıklayan tablolar yaptırılabilir" denildiği görülmektedir (akt. Dönmez ve Oruç, 2006, s.58-61). Cumhuriyet döneminde de bu ilgi devam etmiş ve ülkemizde 1943-1946 yıllarında ilk "senkronik tarih şeridi" çalışması gerçekleştirilmiştir. 1943 yılında gerçekleştirilen II. Milli Eğitim Şurası'nda, tarih eğitiminin ve ders materyallerinin iyileştirilmesi ile ilgili alınan kararlar bağlamında "histomap" hazırlanması kararlaştırılmıştır. Hamit Zübeyr Koşay önderliğindeki bir ekip tarafından üç yıllık bir çalışmanın ardından hazırlanan "Tarih Öncesi ve Tarih Çağlarının Mukayeseli Zaman Tablosu (Histomap)", 1931 yılında Sparks tarafından hazırlanan materyalin düzenlenmesi sonucunda oluşturulmuştur (Ata, 2008). 


\section{Ölçekli Senkronik Tarih Şeridi}

Farklı zaman-mekânsal konfigürasyonlardaki olay ve olguların karşılaştırılmasına veya birlikte değerlendirilmesine imkân sağlayabilmek için farklı mekânsal ölçek ve zamansal çözünürlük derecelerine sahip üç senkronik tarih şeridi (STŞ) hazırlanmıştır. Bunlar Yakın Çağ (17892018), 1900-1940 ve Türk İstiklal Harbi başlıklı senkronik tarih şeritleridir.

STŞ'lerin hazırlanmasında yaklaşık üç asırlık geçmişi olan geleneksel özelliklerine riayet edilmiştir. Bu özellikler;

- Devletlerin, siyasi teşkilatlanmaların coğrafi birimler üzerindeki mekânsal dağılımı,

- Devletlerin, siyasi teşkilatlanmaların zamana göre dağılımı,

- Tarihi olayların, zaman ve mekân içerisindeki dağılımının görselleştirilmesidir.

Bu geleneksel özelliklerin yanında hazırlanan STŞ'lerin ilgili alanyazına kazandırdığı bazı yeni özellikler de bulunmaktadır. Bu yenilikler şu şekilde sıralanabilir:

- Yakın Çă̆’ın zaman-mekânsal gösterimi,

- Mekânsal temsilde manipülasyonun önüne geçen ve temsilin objektifliğini arttıran ölçeklendirme tekniğii,

- Zaman-mekânsal verilerin, analiz birimlerini değiştirmeye imkân sağlayacak şekilde mekânsal ölçek ve zamansal çözünürlük derecelerine göre katmanlı şekilde temsil edilmesi.

Üç farklı STŞ'de yukarıda sunulan senkronik yaklaşım modelinin farklı katmanlarında yer alabilecek olay ve olgu örnekleri sergilenmiştir. Aşağıda bu STŞ'lerin özellikleri ve senkronik yaklaşım modeli bağlamındaki birbirleriyle olan ilişki durumları ayrıntılı şekilde ele alınmıştır.

\section{Yakın Çă̆ Ölçekli Senkronik Tarih Şeridi}

Senkronik yaklaşım modeline göre geniş ölçekli zaman-mekânsal senkronizasyon katmanında değerlendirilebilecek Yakın Çă̆ Senkronik Tarih Şeridi; 1789-2018 yılları arasında Avrupa, Ortadoğu, Türkistan ve Kuzey Afrika'da meydana gelen olay ve olguları görsel bir şekilde eş zamanlı olarak sunmaktadır.

Mekân faktörü yatay olarak uzanan satırlarla ölçekli şekilde temsil edilirken; zaman faktörü eşit aralıklı dikey çizgilerle gösterilmiştir. STŞ’nin çalışma alanına kazandırdığı en önemli yenilik, mekân boyutu ile ilgili manipülasyon olasılığının önüne geçilmesini sağlayan ölçeklendirme tekniğidir. Bu teknik doğrultusunda mekânlar (coğrafyalar), yüzölçümlerine oranlanmış satır yükseklikleriyle temsil edilmiştir. Farklı mekânlar için ayrılan satır yüksekliklerinin değişkenliği net bir şekilde görülmektedir (bkz. Şekil-2). Bu satır yükseklikleri belirlenirken, farklı mekânlara ait yüzölçümleri, belirli bir ölçek dâhilinde küçültülerek cm cinsinden uzunluk ölçüsüne dönüştürülmüştür. Böylelikle yüzölçümü bakımından daha büyük olan coğrafi birimler, yüzölçümü daha küçük olanlara göre daha yüksek bir satır (şerit) aralığıyla temsil edilmiştir. Üzerinde çalışılan alanların yüzölçümlerinin hesaplanmasında "Google Earth" uygulamasından yararlanılmıştır. Devletlerin tarihi süreç içerisinde değişen sınırlarının tespitinde ise "GeaCron" ve "Running Reality" uygulamaları ile tarih atlasları ve haritalarından faydalanılmıştır. Tablo 1'de Yakın Çağ Senkronik Tarih Şeridi'nde, 1789-2018 yılları arasındaki tarihi gösterilen coğrafyalar sunulmuştur: 
Tablo 1. Yakın Çağ Senkronik Tarih Şeridinde Gösterilen Coğrafyalar

\begin{tabular}{|c|c|c|c|c|c|c|c|}
\hline Nu. & Mekân/Coğrafya & $\mathrm{Nu}$. & Mekân/Coğrafya & $\mathrm{Nu}$. & Mekân/Coğrafya & $\mathrm{Nu}$. & Mekân/Coğrafya \\
\hline 1. & Doğu Türkistan & 11. & Suriye & 21. & Rusya & 31. & İtalya \\
\hline 2. & Tacikistan & 12. & Irak & 22. & Ukrayna & 32. & İsviçre \\
\hline 3. & Kazakistan & 13. & Arabistan & 23. & Beyaz Rusya & 33. & Britanya \\
\hline 4. & Kırgızistan & 14. & Yemen & 24. & Polonya & 34. & İrlanda \\
\hline 5. & Özbekistan & 15. & Umman & 25. & Çekoslovakya & 35. & Misır \\
\hline 6. & Türkmenistan & 16. & B.A.E. & 26. & Macaristan & 36. & Sudan \\
\hline 7. & İran & 17. & Filistin & 27. & Avusturya & 37. & Libya \\
\hline 8. & Azerbaycan & 18. & Yunanistan & 28. & Almanya & 38. & Tunus \\
\hline 9. & Güney Kafkasya & 19. & Bulgaristan & 29. & Benelüks & 39. & Cezayir \\
\hline 10. & Türkiye & 20. & Romanya & 30. & Fransa & 40. & Fas \\
\hline
\end{tabular}

Tablo 1'de görüldüğü üzere, mekân faktöründe kullanılan coğrafi birimler çoğunlukla bugünkü ülkelerdir. Bunun temel sebebi, ölçekleme işlemini sağlıklı bir şekilde gerçekleştirebilmek için net sınırlara ihtiyaç duyulmuş olmasıdır. Ayrıca bu tip bir mekânsal iskelet tercihinin, günümüz okuyucusunun STŞ’yi daha rahat anlamasına vesile olacağı düşünülmüştür. Yakın Çağ Senkronik Tarih Şeridi (1789-2018) Şekil 3'te gösterilmiştir.

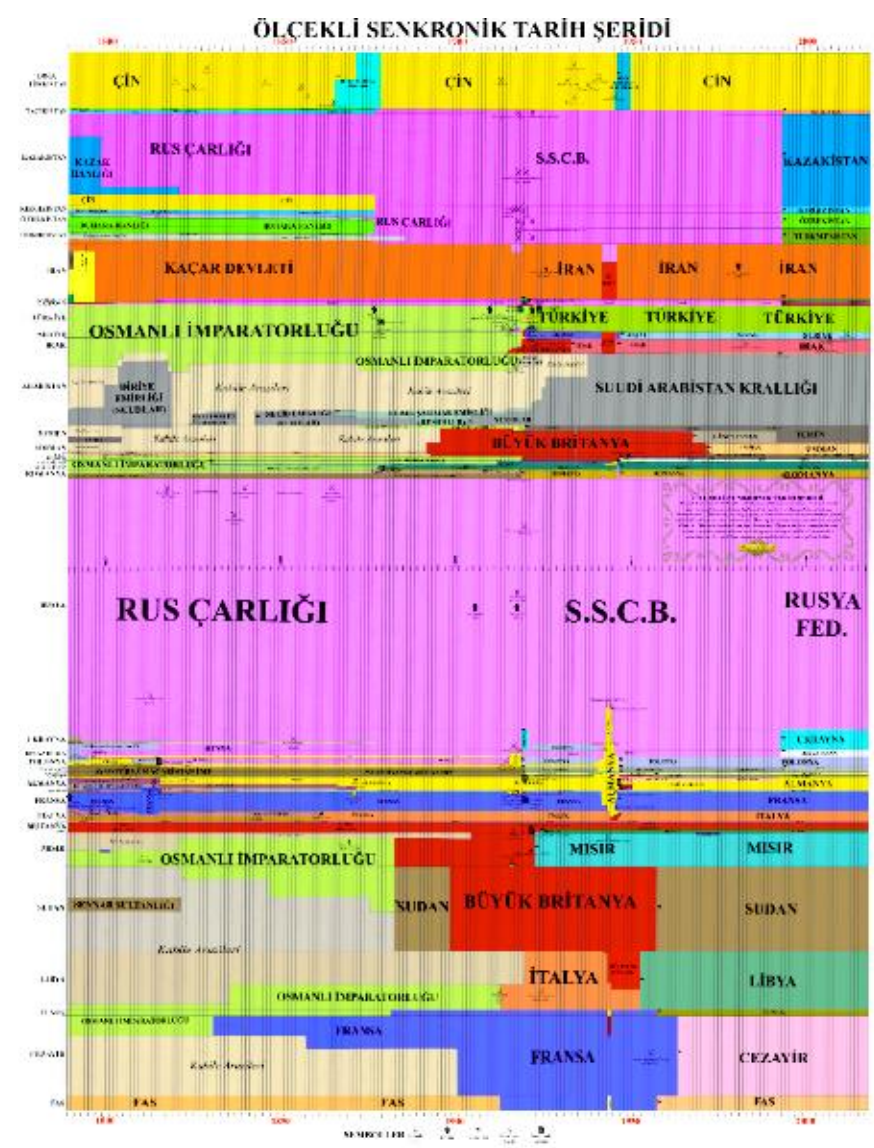

Şekil 3. Yakın Çağ Ölçekli Senkronik Tarih Şeridi (1789-2018)

Şekil 3'te görüldüğü üzere; Tablo 1'de sunulan coğrafyalarda varlık göstermiş devletlerin zaman-mekânsal dağılımı ayrıntılı şekilde sunulmuştur. Yıllara göre gerçekleşen sınır ve hanedan değişiklikleri, savaşların zaman ve mekân içerisindeki konumları ile sınır değişiklikleri üzerindeki etkisi, günümüzün dünyasında hâkim olan ulusal ve uluslararası siyasi sistemin arka 
planında yatan tarihi manzara bir bütün olarak göz önüne serilmiştir. Fransız İhtilali ve sonrasında yaşananlar, Napolyon Savaşları, Osmanlı İmparatorluğu ve diğer imparatorlukların parçalanışı, 1. ve 2. Dünya Savaşlarının etkileri vb. olay ve olgular görsel olarak takip edilebilmektedir. Belirli bir coğrafyada soldan-sağa gezinerek o coğrafyadaki tarihin akışını diyakronik (art zamanlı) bir perspektifle tecrübe etmek mümkünken; aynı zamanda yukarı ve aşağı gezinerek eş zamanlı olayları senkronik bir perspektifle değerlendirmek de mümkündür.

\section{0-1940 Ölçekli Senkronik Tarih Şeridi}

Senkronik yaklaşım modeline göre orta ölçekli zaman-mekânsal senkronizasyon katmanında değerlendirilebilecek olan 1900-1940 Ölçekli Senkronik Tarih Şeridi, bahsi geçen yıl aralığında Kuzey Afrika, Ortadoğu, Türkiye ve Balkanların bir bölümünde meydana gelen olay ve olguları eş zamanlı olarak sunmaktadır. Bu senkronik tarih şeridinde de, ilkinde (Yakın Çağ STŞ) olduğu gibi mekân faktörü yatay olarak uzanan satırlarla temsil edilirken; zaman faktörü eşit aralıklı dikey çizgilerle gösterilmiştir. Ölçekleme metodu bu STŞ'de de kullanılmıştır. Tablo 2'de 1900-1940 STŞ'de gösterilen coğrafi birimler sunulmuştur:

Tablo 2. 1900-1940 Senkronik Tarih Şeridinde Gösterilen Coğrafyalar

\begin{tabular}{ll}
\hline Nu. & Mekân/Coğrafya \\
\hline 1. & Libya \\
\hline 2. & Misır \\
\hline 3. & Ürdün \\
\hline 4. & Irak \\
\hline 5. & Suriye \\
\hline 6. & Türkiye \\
\hline 7. & Yunanistan \\
\hline 8. & Bulgaristan \\
\hline
\end{tabular}

Tablo-2'de görüldüğü üzere bu STŞ'de de ilkinde olduğu gibi mekân faktöründe kullanılan coğrafi birimler ülkelerdir. 1900-1940 Ölçekli Senkronik Tarih Şeridi, Şekil 4'te gösterilmiştir: 


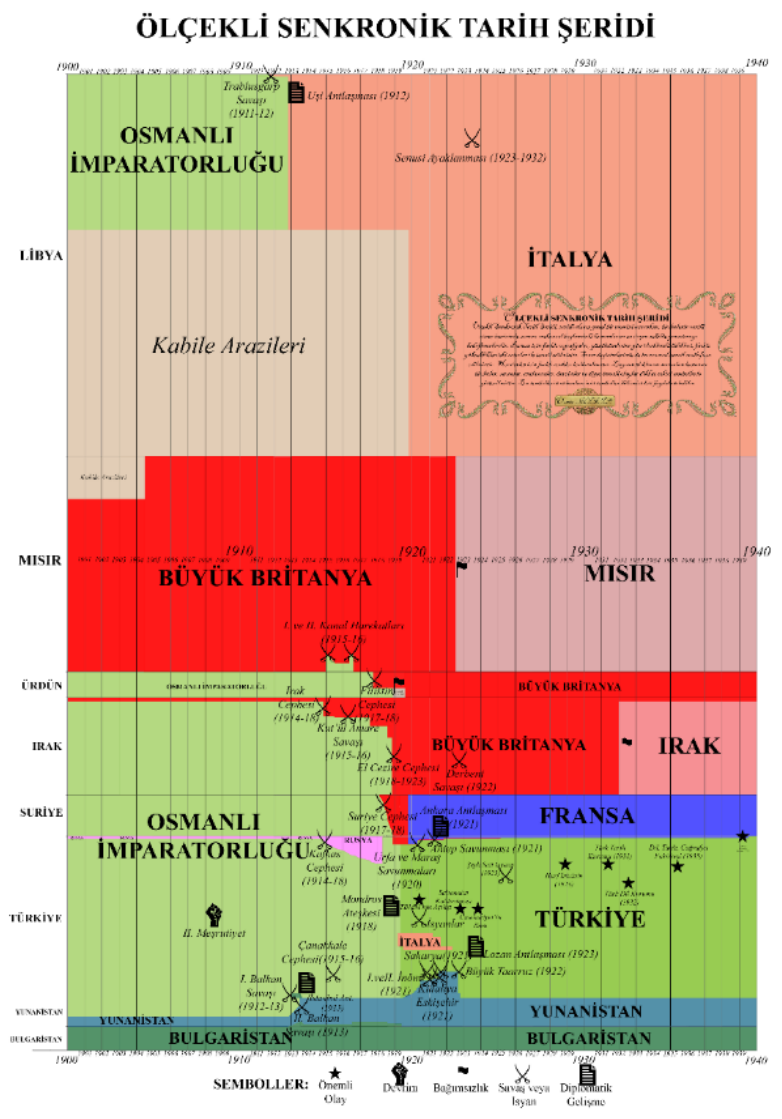

Şekil 4. 1900-1940 Ölçekli Senkronik Tarih Şeridi

Şekil 4'te görüldüğü üzere; Tablo 2'de sunulan coğrafyalarda varlık göstermiş devletlerin zaman-mekânsal dağılımı ayrıntılı şekilde sunulmuştur. Yıllara göre gerçekleşen sınır ve yönetim değişiklikleri, savaşların zaman ve mekân içerisindeki konumları ile sınır değişiklikleri üzerindeki etkisi, söz konusu coğrafyalarda günümüzün dünyasında hâkim olan ulusal ve uluslararası siyasi sistemin arka planında yatan tarihi manzara bir bütün olarak sunulmuştur. Trablusgarp Savaşı (1911), Balkan Savaşları (1912-1913), Birinci Dünya Savaşı (1914-1918), Türk İstiklal Harbi (1919-1922), antlaşmalar vb. olay ve olgular görsel olarak takip edilebilmektedir.

Orta ölçekli zaman-mekânsal senkronizasyon katmanı için bu coğrafyaların ve yıl aralığının seçilme sebebi, dar ölçekli zaman-mekânsal senkronizasyon katmanında sunulan Türk İstiklal Harbi'ni hazırlayan şartlar ve tarihi arka planın ortaya çıkarılabilmesi ve bu coğrafyalarda eş zamanlı olarak gerçekleşen olaylarla irtibatının kurulabilmesini sağlamaktır. Yakın Çağ Ölçekli Senkronik Tarih Şeridi için de aynı durumdan bahsedilebilir.

\section{İstiklal Harbi Ölçekli Senkronik Tarih Şeridi}

Senkronik yaklaşım modeline göre dar ölçekli zaman-mekânsal senkronizasyon katmanında değerlendirilebilecek olan İstiklal Harbi Ölçekli Senkronik Tarih Şeridi, bahsi geçen yıl aralığında Türkiye'nin yedi bölgesinde meydana gelen olay ve olguları eş zamanlı olarak sunmaktadır. Bu senkronik tarih şeridinde, ilk ikisinde (Yakın Çă̆ STŞ ve 1900-1940 STŞ) görülenin aksine mekân faktörü dikey olarak uzanan sütunlarla temsil edilirken; zaman faktörü eşit aralıklı yatay çizgilerle gösterilmiştir. Ölçekleme metodu bu STŞ'de de kullanılmıştır. Tablo 3'te İstiklal Harbi Senkronik Tarih Şeridi'nde gösterilen coğrafi birimler sunulmuştur: 
Tablo 3. İstiklal Harbi Senkronik Tarih Şeridinde Gösterilen Coğrafyalar

\begin{tabular}{ll}
\hline Nu. & Mekân/Coğrafya \\
\hline 1. & Ege Bölgesi \\
\hline 2. & Marmara Bölgesi \\
\hline 3. & İç Anadolu Bölgesi \\
\hline 4. & Akdeniz Bölgesi \\
\hline 5. & Güneydoğu Anadolu Bölgesi \\
\hline 6. & Doğu Anadolu Bölgesi \\
\hline 7. & Karadeniz Bölgesi \\
\hline
\end{tabular}

Tablo 3'te görüldüğü üzere bu STŞ'de mekân faktöründe kullanılan coğrafi birimler, Türkiye içerisindeki coğrafi bölgelerdir. Ölçekleme işlemini sıhhatli bir şekilde gerçekleştirebilmek için ihtiyaç duyulan "net" coğrafi sınırlar sebebiyle, Türkiye'nin içerisinde sınırları belirli olan yedi coğrafi bölge STŞ'de coğrafi birimler olarak kullanılmıştır. Türk İstiklal Harbi Ölçekli Senkronik Tarih Şeridi, Şekil 5'de gösterilmiştir:

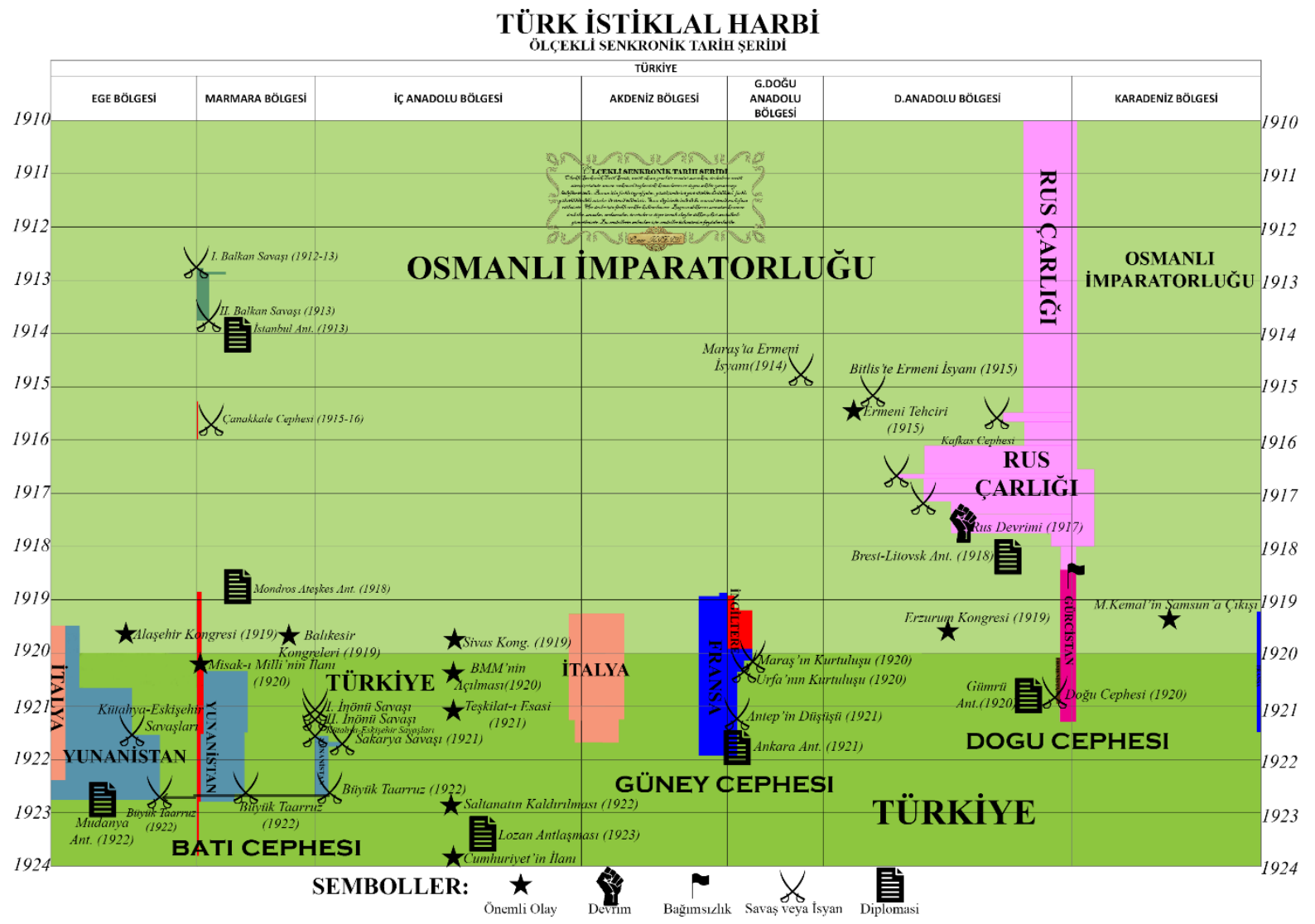

Şekil 5. Türk İstiklal Harbi Ölçekli Senkronik Tarih Şeridi.

Şekil 5'de görüldüğü üzere; Tablo 3'te sunulan bölgeleri işgale girişmiş devletlerin, işgal faaliyetlerinin zaman-mekânsal dağılımı ayrıntılı şekilde sunulmuştur. Y1llara göre gerçekleşen sınır değişiklikleri; savaşların zaman ve mekân içerisindeki konumları ile sınır değişiklikleri üzerindeki etkisi bir bütün olarak sunulmuştur. Birinci Dünya Savaşı öncesi ve esnasındaki Rus işgali, Balkan Savaşları (1912-1913), İnönü Savaşları (1921), Kütahya-Eskişehir Savaşları (1921), Sakarya Savaşı (1921), Büyük Taarruz (1922), antlaşmalar vb. olay ve olgular görsel olarak sunulmuştur. Türk İstiklal Harbi'nin öncesinde, esnasında ve sonrasında yaşananların 
Türkiye'nin bölgelerine göre dağıtılmış şekildeki sunumu, önceki iki STŞ'de sunulan verilerle bağlantılı şekilde değerlendirildiğinde İstiklal Harbi ve sonrasındaki inkılapların arka planında yatan tarihi panorama netlik kazanmaktadır. Bunun farkına varılmasını sağlayacak ve bu görüyü geliştirebilecek en önemli faktör, tarih konularının öğretimi sürecinde kazanım, içerik, yöntem ve değerlendirme boyutlarının planlamasında senkronik yaklaşım modelinin göz önünde bulundurulmasıdır.

\section{SONUÇ VE ÖNERILER}

Tarih konularının öğretiminde yaygın olarak kullanılan diyakronik zaman nosyonunun yerine senkronik zaman nosyonunun önerildiği ve bu konuya örnek bir yaklaşım modeli sergilenen bu çalışma, alanyazında benzer çalışmaların bulunmaması sebebiyle farklı araştırmalarla karşılaştırılamamıştır. Esasında çalışmanın temel amacı da alanyazına senkronik yaklaşım modelini kazandırmak ve bu konuya dikkat çekerek tartışmaya açmaktır. Bu bağlamda ortaya konulan senkronik yaklaşım modeli kapsamında, farklı zaman-mekânsal analiz düzeyleri içerisinde üç katmanlı zaman-mekânsal bir konfigürasyon sergilenmiştir. Bu katmanlar, incelenen coğrafyanın ve zaman aralığının genişliğine bağlı olarak dar, orta ve geniş ölçekli zaman-mekânsal senkronizasyon katmanı olarak isimlendirilmiştir. Analiz edilen tarihi olayların bağlantılı olduğu olgular göz önünde bulundurularak bu analiz düzeylerinin sayısı arttırılabilir veya azaltılabilir. Örnek olay olarak incelenen Türk İstiklal Harbi bağlamında dar, orta ve geniş ölçekli katmanlar içerisinde yer verilen olaylar, olgular, devletler, coğrafyalar ve zaman aralıkları göz önünde bulundurulduğunda; herhangi bir tarihi olay için bu yaklaşımın ne şekilde kullanılabileceği anlaşılır olmaktadır. Bu bağlamda söz konusu analiz düzeylerini görünür kılan ölçekli senkronik tarih şeritlerine büyük iş düşmektedir. Bu bağlamda çalışmanın bir diğer boyutunu, senkronik yaklaşım modeli kapsamında kullanılması öngörülen ölçekli senkronik tarih şeridi çalışmaları oluşturmaktadır.

Alanyazın senkronik tarih şeridi çalışmaları bakımından oldukça zengin olup; bu şeritlerin tarih konularının öğretimi hususunda kullanımı bakımından oldukça yoksundur. $\mathrm{Bu}$ çalışma kapsamında "Yakın Çağ ölçekli senkronik tarih şeridi (1789-2018)", "1900-1940 ölçekli senkronik tarih şeridi" ve "Türk İstiklal Harbi ölçekli senkronik tarih şeridi” başlıklı üç senkronik tarih şeridi hazırlanmıştır.

Senkronik tarih şeritlerinin hazırlanmasında, alanyazının yaklaşık üç asırlık geçmişinde rastlanan geleneksel özelliklere riayet edilmiştir. Bu özellikler;

- Devletlerin, siyasi teşkilatlanmaların coğrafi birimler üzerindeki mekânsal dağılımı,

- Devletlerin, siyasi teşkilatlanmaların zamana göre dağılımı,

- Tarihi olayların, zaman ve mekân içerisindeki dağılımının görselleştirilmesidir.

$\mathrm{Bu}$ benzer özelliklere ek olarak, hazırlanan ölçekli senkronik tarih şeritleri alanyazındaki çalışmalarla karşılaştırıldığında, senkronik tarih şeridi hazırlama teknikleri ve özellikleri bakımından bazı özgün nitelikleri ile ön plana çıkmaktadır. Alana kazandırılan bu yeni özellikler şu şekilde sıralanabilir:

- Yakın Çağ’ın zaman-mekânsal gösterimi, 
- Mekânsal temsilde manipülasyonun önüne geçen ve temsilin objektifliğini arttıran ölçeklendirme tekniğii,

- Zaman-mekânsal verilerin, analiz birimlerini değiştirmeye imkân sağlayacak şekilde mekânsal ölçek ve zamansal çözünürlük derecelerine göre katmanlı şekilde temsil edilmesi.

Bu çalışma kapsamında hazırlanan ölçekli senkronik tarih şeritlerinin aksine Bruyere, (1750), Jefferys (1750), Priestley (1769), Sparks (1931), Adams (2007), Rosenberg ve Grafton (2010) gibi isimlerin çalışmaları incelendiğinde, bu alandaki en tanınmış örneklerde dahi mekânın temsili boyutunda bir keyfiyetin söz konusu olduğu ve genelde Batı Uygarlığı odaklı bir manipülasyonun sahnelendiği görülmektedir. $\mathrm{Bu}$ durum ise geçmişin zaman-mekânsal haritalanmasının gerçeğe uygun şekilde gerçekleşmesinin önüne geçmekte ve Batı Uygarlığını diğer uygarlık sahalarına göre daha "önemli" ve "görünür" kılmaktadır. Çalışma kapsamında hazırlanan ölçekli senkronik tarih şeritleri format bakımından diğer çalışmalara (Jefferys, 1750; Priestley, 1769) benzese de özellikle mekânın temsil boyutundaki ölçekleme tekniği ile diğerlerinden ayrılmakta ve objektif kriterlere dayalı temsil kabiliyetiyle mekânsal manipülasyonun önüne geçmektedir. Bu durum tarihi olay ve olguların daha gerçekçi ve doğru bir şekilde zaman-mekânsal temsilini mümkün kılmaktadır.

Hazırlanan ölçekli senkronik tarih şeritlerinin alanyazına kazandırdığı bir diğer yenilik ise farklı zaman-mekânsal çözünürlük ve ölçeklerdeki temsil kabiliyetidir. Sunulan senkronik yaklaşım modeli kapsamında dar, orta ve geniş ölçekli zaman-mekânsal senkronizasyon katmanları olarak adlandırılan analiz düzeylerinin her biri farklı zaman aralıkları ve farklı genişlikteki coğrafyaların haritalandırılmasında kullanılmıştır. Materyallerin temsil ettiği verilerin özellikleri, haritalardaki ölçeklendirme tekniğine benzer şekilde işlemektedir. Temsil edilen mekân genişledikçe (ölçek küçüldükçe) zamana karşı duyarlılık azalmakta ve daha geniş zaman birimlerini işletmek söz konusu olmaktadır. Örneğin model kapsamında, geniş ölçekli zamanmekânsal senkronizasyon katmanında yer alan verilerin görselleştirilmesi için hazırlanan "Yakın Çağ ölçekli senkronik tarih şeridi” Avrupa'dan Çin'e, Rusya'dan Kuzey Afrika'ya kadar çok geniş bir coğrafyayı görselleştirirken zaman birimi olarak günler, aylar ve hatta bir ölçüye kadar yıllar dahi anlamını yitirmekte; tarihin panoraması on yıllar ve asırlar üzerinden izlendiğinde daha anlamlı sonuçlara ulaşılmaktadır. Dolayısıyla gün, ay, yıl gibi zaman birimlerine yönelik duyarlılığın zayıfladığı söylenebilir. Orta ölçekli zaman-mekânsal senkronizasyon katmanı için hazırlanan "1900-1940 ölçekli senkronik tarih şeridi”nde ise ele alınan coğrafya daralmakta (ölçek büyümekte) ve zamana karşı duyarlılık bir önceki çalışmaya göre artmaktadır. Bu materyal üzerinde gerçekleştirilecek düşünme süreçlerinde yıllar anlam kazanmaktadır. Dar ölçekli zaman-mekânsal senkronizasyon katmanı için hazırlanan "Türk İstiklal Harbi ölçekli senkronik tarih şeridi"nde ise ele alınan coğrafya iyiden iyiye daralmıştır (ölçek büyümüştür). Bu çalışmada yalnızca günümüz Türkiye coğrafyası, 1910-1924 yılları arasındaki tarihi ile konu edilmektedir. Dolayısıyla zamana karşı duyarlılık önceki iki çalışmaya göre oldukça artmış olup; bu materyal üzerinde gerçekleştirilen düşünme süreçlerinde günler, aylar ve yıllar anlam kazanmaktadır. Diğer yandan yalnızca bu materyal ile on yıllar ve asırlar üzerinden bir okuma yapmak mümkün değildir. Bunun için diğer senkronizasyon katmanlarını temsil eden materyallere başvurmak gerekmektedir. Türk İstiklal Harbi'nin Türkiye'nin yakın coğrafyasının konjonktürü ile bağlantısını kurabilmek için 19001940 ölçekli senkronik tarih şeridi; Türk İstiklal Harbi'ne sebep olan ve asırlara yayılan olay ve olgularla bağlantısının kurulabilmesi için ise Yakın Çağ ölçekli senkronik tarih şeridi ile birlikte kullanılması gerekmektedir. Görüldüğü üzere bu tip bir işlem için üç farklı senkronik 
tarih şeridinin birlikte kullanılması ve ölçeğin zihnen kaydırılması gerekmektedir. Üç farklı materyalin kullanımına ihtiyaç duyulmasının bu konuda bir handikap yarattığı söylenebilir. Bu sorunu çözmek için basılı materyaller kullanmak yerine yeni çalışmalarda zaman-mekânsal senkronizasyon katmanları arasında geçişe imkân sağlayan dijital ölçekli senkronik tarih şeritlerinin hazırlanması önerilmektedir. Araştırmacılara ve uygulayıcılara yönelik diğer öneriler şu şekilde sıralanabilir:

- Farklı coğrafya ve zaman aralıklarını konu edinen ölçekli senkronik tarih şeritlerinin hazırlanmasi,

- Ölçekli senkronik tarih şeritlerinin, tarih konularının öğretiminde kullanılması,

- Ölçekli senkronik tarih şeritlerinin, öğrencilerin akademik başarı düzeyleri üzerindeki etkisinin araştırılması,

- Ölçekli senkronik tarih şeritlerinin, farklı düşünme becerileri üzerindeki etkilerinin araştırılması,

- Ölçekli senkronik tarih şeritleri ile ilgili etkinlik, ölçme ve değerlendirme materyallerinin hazırlanması.

\section{KAYNAKÇA}

Adams (2007). Adams synchronological chart of map of history: Teacher's guide. Master Books.

Alcalde, Á. (2018). Spatializing transnational history: European spaces and territories. European Review of History: Revue européenne d'histoire, 25(3-4), 553-567.

Andrienko, N., Andrienko, G., \& Gatalsky, P. (2003). Visual data exploration using space-time cube. Proceedings of the 21 st International Cartographic Conference (ICC) (pp. 1981-1983). The International Cartographic Association (ICA).

Aristoteles. (2017). Fizik. (S. Babür, Çev.). Yapı Kredi Yayınları.

Arnheim, R. (2015). Görsel düşünme. (R. Öğdül, Çev.). Metis Yayıncılık.

Ata, B. (2006). Üniversite öncesi tarih ögrretiminde siyasi tarihin yeri [Bildiri sunumu]. Türkiye'de Siyasi Tarih'in Gelişimi ve Sorunları Sempozyumu (ss. 31-48), Ankara Üniversitesi Siyasal Bilgiler Fakültesi, Ankara.

Ata, B. (2008). 1943'teki ikinci Milli Eğitim şurasının tarih eğitimi kararlarından birinin uygulanması: Bir histomap'in yapım öyküsü. Kuram ve Uygulamada Eğitim Bilimleri, 8(2), 335-353.

Ata, B. (2009). Johann Friedrich Herbart'ın tarih eğitimi üzerine görüşleri. Gazi Eğitim Fakültesi Dergisi, 2(29), 97-115.

Bergson, H. (2017). Yaratıcı tekâmül. (M. Ş. Tunç, Çev.). Dergâh Yayınları.

Bruyere, J. B. (1750). The mappemonde historique. Buache. http://catalogue.bnf.fr/ark:/12148/cb40753112q

Clemens, L. (2014). The effectiveness of uncertainty visualization in a "coordinated multiple view" environment using a temporal dataset (case study). [Master's Thesis, Technische Universität Dresden].

Dönmez, C., \& Oruç, Ş. (2006). II. Meşrutiyet dönemi tarih öğretimi. Gazi Kitabevi.

Dönmez, C., \& Yazıcı, K. (2008). T.C. inkılap tarihi ve atatürkçülük konularının öğretimi. Nobel Yayıncılık.

Gaddis, J. L. (2002). The landscape of history: How historians map the past. Oxford University Press.

Hagerstrand, T. (1982). Diorama, path and project. Tijdschrift voor Economische en Sociale Eografie, 323-339.

Harms, J., \& Lettow, L. (2007). Nurturing children's concepts of time and chronology through literature. Childhood Education, 83(4), 211-218.

Hroch, M. (2011). Avrupa'da milli uyanış: Toplumsal koşulların ve toplulukların karşılaştırmalı analizi. İletişim Yayınları. 
İbni Rüşd (2018). Faslu’l makal/Felsefe ve din uyumu. Elis Yayınları.

Jefferys, T. (1750). A chart of universal history.

Keskin, M. Doğru, A. Uluğtekin, N. \& Güney, C. (2020, Haziran 03). Zaman-mekân kübünün (space-time cube) anlaşılabilirliğinin değerlendirilmesi. TMMOB Harita ve Kadastro Mühendisleri Odası. https://www.hkmo.org.tr/resimler/ekler/f5f6f2323046f1a_ek.pdf

Kneeshaw, S. (1988a). The 1920's and 1970's: Introducing comparative history into the classroom. OAH Magazine of History, 3(3/4), 13-15.

Kneeshaw, S. (1988b). Comparative history in the classroom: A lesson plan. OAH Magazine of History, 3(3/4), 43.

Köktürk, M. (2017). Zaman üzerine felsefi soruşturma. Ötüken.

Lacoste, Y. (2014). Coğrafya her şeyden önce savaş yapmaya yarar. (S. Sezer, Çev.). Ayrıntı Yayınları.

Mazur, J. (2018). Matematik sembollerinin kısa tarihi. (B. Gönülşen, Çev.). Türkiye İş Bankası Kültür Yayınları.

Mullaw, B. D. (2008). Geo visualization of movements: moving objects in static maps, animation and the space time cube. International Institute for Geo-Information Science and Earth Observation.

NCHS. (1996). National standards for history. National Center for History.

Pinker, S. (2018b). Zihin nasıl çalışır? Zihnin evrimsel ve nörobilimsel incelemesi. (S. Gürses, Çev.). Alfa.

Priestley, J. (1769). A description of a new chart of history. J. Johnson.

Rosenberg, D., \& Grafton, A. (2010). Cartographies of time. Princeton Architectural Press.

Safran, M. (2002). Türk tarihi öğretimi ve meseleleri. Türkler Ansiklopedisi, 17, 935-942.

Safran, M., \& Şimşek, A. (2009). Tarih yazımında bir sorun: Tarih ve zaman ilişkisi. Tarihin Peşinde Uluslararası Tarih ve Sosyal Araştırmalar Dergisi, 1(1), 9-26.

Safran, M. \& Şimşek, A. (2011). Anlatı bağlamında tarihyazımının sorunları. Bilig, 59, 203-234.

Solso, R. L., MacLin, M. K., \& MacLin, O. H. (2018). Bilişsel psikoloji. (A. Ayçiçerği-Dinn, Çev.) Bilge KültürSanat.

Sparks, J. (1931). The Histomap: four thousand years of World history, relative power of contemporary states, nations and empires. Histomap Inc and Rand McNally.

Şengül Bircan, T. \& Safran, M. (2013). Tarih öğretiminde haritaların önemi ve kullanımı. Ahi Evran Üniversitesi Kırşehir Eğitim Fakültesi Dergisi, 14(2), 461-476.

Şimşek, A. (2006). İlköğretim ögrrencilerinde tarihsel zaman kavramının gelişimi ve öğretimi. [Doktora Tezi, Gazi Üniversitesi Eğitim Bilimleri Enstitüsü].

Tütüncü, G. \& Ünal N. (2019). Karşılaştırmalı tarih: Doğuşu, gelişimi, metodolojisi ve Türkiye'deki durumu. Al Farabi International Journal of Social Sciences, 3(4), 79-93.

Wach, E., Ward, R., \& Jacimovic, R. (2013). Learning about qualitative document analysis. IDS Practice Paper in Brief, 13, 1-9.

https://opendocs.ids.ac.uk/opendocs/bitstream/handle/20.500.12413/2989/PP\%20InBrief\%2013\%20QD A\%20FINAL2.pdf?sequence $=4$

Windhager, F. (2013). On polycubism. Outlining a dynamic information visualization framework for the humanities and social sciences. M. Füllsack (Ed.) Networking networks: origins, applications, experiments içinde (s. 28-64). Institute of Systems Sciences, Innovation and Sust.

Yılmaz, D. \& Taşer, S. (2009). Tarih ĕgitiminde karşılaştırmalı öğretim tekniğinin yeri ve önemi. Eğitim Araştırmaları Birliği. http://www.eab.org.tr/eab/2009/pdf/124.pdf 


\section{EXTENDED ABSTRACT}

\section{The Model of Synchronic Approach and Scaled Synchronological Charts To Teaching Historical Subjects}

These are diachronic and synchronic approaches. Today, the diachronic approach is used more widely than the synchronic approach. Historical events and phenomena occur in connection with other events and phenomena within time and space. The diachronic understanding of history has reduced this connection between events and phenomena to a causal chain over time. This situation manipulates the perception of history, which is an epistemological structure in nature, by ignoring space. In historiography, the comparative history method has largely eliminated this problem. Comparative history method is closely related to synchronic thinking skills. However, comparative history has not yet seen a systematic effect on the teaching of history subjects.

The "grounded theory" method were used in this study. The unique nature of the subject to be researched, the demonstration of the dimensions and elements of synchronic thinking skills and the fact that its relation with other thinking skills were researched had an impact on adopting the grounded theory approach. In the study, data were collected using the document review method. Collected data were analyzed using content analysis technique.

In this study, based on the comparative history and synchronological chart studies; A synchronic approach model that can be used in the teaching of history subjects has been introduced. In this context, synchronological charts that can be used within the scope of the developed model were prepared. Synchronological charts have nearly three centuries of tradition. These materials are one of the limited number of tools that allow for a time-spatial representation of history. Although very old examples are found in Europe and the United States of America, there are few studies in this area in our country. Existing studies have failed to add any innovation to the literature on synchronological charts.

In the synchronological charts prepared in Europe and the USA, it is seen that the space factor is manipulated in favor of Europe and the USA. This situation causes the Western Civilization to be represented in a way that it seems "bigger" and more "important" compared to other civilizations. For this reason, the lack of a standard method for the space factor in synchronological charts creates problems in the production of objective works. In this study, a method that solves this problem regarding synchronological charts and provides objective timespatial representation has been developed and applied. The synchronological chart prepared maps the historical process in Europe, Turkistan, the Middle East and North Africa between 1789-2018 in a time-spatial manner. The innovations brought to the field by the prepared study can be listed as follows: (1) Time-spatial depiction of the Modern Age; (2) scaling technique that prevents manipulation in spatial representation and increases the objectivity of representation; (3) layered representation of time-spatial data according to spatial scale and temporal resolution. 
In another experimental study, it was seen that the use of the method and the use of synchronological charts improved students' spatial and synchronic thinking skills. The study was completed with suggestions for further research.

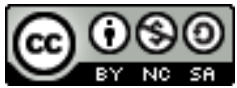

"International Journal of New Approaches in Social Studies - IJONASS" is licensed under a Creative Commons Attribution-NonCommercial-ShareAlike 4.0 International License. 